CESIS Electronic Working Paper Series

Paper No. 481

\title{
Crowdfunding as Gambling: Evidence from Repeated Natural Experiments
}

\author{
Tolga Demir \\ Ali Mohammad \\ Kourosh Shafi
}

September, 2019 


\title{
Crowdfunding as Gambling: Evidence from Repeated Natural Experiments
}

\author{
Tolga Demir, Ali Mohammadi, and Kourosh Shafi* ${ }^{* \dagger}$
}

July 31, 2019

\begin{abstract}
We explore whether sensation-seeking, a personality trait that involves risk-taking for novelty and thrill, is one of the underlying motivations for participating in peer-to-peer lending crowdfunding markets. To empirically substantiate this argument, we test whether individuals participating in Prosper, one of the largest lending markets in the U.S., reduce their lending activity when gambling in the form of playing the multistate lotteries Powerball and Mega Millions becomes more attractive. Lottery is a repeated natural experiment: lottery jackpots are randomly won and a series of draws with no winners form large jackpots. We find that the thrill of winning a large jackpot lottery, perhaps intensified by advertising and media coverage around this event, fulfills some lenders' desire of sensation-seeking and substitutes participating in Prosper, decreasing their lending activity. We discuss implications for lenders and borrowers, as well as platform organizers and policy makers.
\end{abstract}

JEL Classification: G23, G41.

Keywords: Peer-to-peer lending, crowdfunding, lottery, gambling, Fin-Tech.

*Tolga Demir, Sabanci University, tolgademir@sabanciuniv.edu; Ali Mohammadi, Copenhagen Business School and Centre of Excellence for Science and Innovation Studies (CESIS), Royal Institute of Technology. amo.si@cbs.dk; Kourosh Shafi, California State University East Bay. kourosh.shafi@csueastbay.edu.

${ }^{\dagger}$ We owe thanks to Stefano Bonini, Massimo Colombo, Eric Fricke, Per Strömberg, Andrea Zaffino and participants in Birmingham Business School and the Journal of Corporate Finance Co-sponsored Conference: Developments in Alternative Finance, the 4th Entrepreneurial Finance Conference, Trier, Stockholm School of Economics, and Copenhagen Business School for helpful comments and discussions. All remaining errors are our own. 


\section{Introduction}

Riddled with substantial challenges from obtaining financing from traditional sources such as banks, many individuals and entrepreneurs have turned to crowdfunding (Block, Colombo, Cumming, and Vismara, 2018; Cumming and Groh, 2018), which involves an open call, essentially through the Internet, for requesting financial resources from crowds (Belleflamme, Lambert, and Schwienbacher, 2014). By removing financial barriers and expanding funding opportunities, individuals organizing crowdfunding campaigns directly benefit in myriad ways ranging from experimentation in the form of commercializing new products and seeking market validation, and creating new ventures and jobs (Mollick, 2016; Signori and Vismara, 2018; Da Cruz, 2018). It is however less clear why people contribute to crowdfunding campaigns; the question of funders' motivations deserves scholarly attention because it is a critical factor in the success of a campaign, or indeed the success of crowdfunding as an alternative source of financing, hailed by policy makers as a new means of financing innovation (Sauermann, Franzoni, and Shafi, 2019; Colombo, Franzoni, and Rossi-Lamastra, 2015a). Essentially, designing the presentation of a crowdfunding campaign that appeals to the crowd requires deep understanding of what motivates backers' giving (Parhankangas and Renko, 2017; Hornuf and Schwienbacher, 2018).

This paper explores whether sensation seeking, defined as a personal trait characterized by an intense desire to experience thrill from risk taking, can explain crowdfunders' contributions, specifically in the form of bids made in peer-to-peer lending crowdfunding. Bidding small amounts and investing in a loan part - like betting in gambling such as lottery - can produce fun, excitement, and thrill. Prior studies that have surveyed crowdfunders about their motivations point to the relevance of "having fun" (Berglin and Strandberg, 2013; Ryu and Kim, 2016; Daskalakis and Yue, 2017), among others; however, survey methods are introspectively derived, and intentional self-assessments and thus, suffer from methodological issues (Nosek, Hawkins, and Frazier, 2011). ${ }^{1}$ Therefore, to empirically identify the variation in pledging activity across individuals explained by the entertainment and fun motivation, we employ the setting of lottery as a form of gambling.

We hypothesize a substitution effect between playing the lottery and bidding activity in peer-to-peer lending market. Our identification strategy is based on the notion that to function as a form of entertainment and fun, funding loan parts needs to compete for attention and dollars with other forms of gambling. One widely available, frequently played, and aggressively

\footnotetext{
${ }^{1} \mathrm{~A}$ few factors limit the value of these explicit measurements to accurately report respondents' mental content by introspection: 1) Respondents might lack motivation for reporting what they are aware of; 2) Respondents might face constrains in reporting: for instances, the design and the circumstances of measurement limit what is reported, or respondents may not feel comfortable answering in ways that present themselves in a unfavorable manner; 3) Respondents might have difficulty in translating their mental content into a report; 4) Respondents might have limits in accessing and recalling their mental content for various reasons including memory decay and displacement; 5) Respondents in survey methods might suffer from non-response bias: Those who choose to respond to a survey question may be different from those who choose not to respond, thus creating bias.
} 
advertised form of gambling is playing the lottery. Accordingly, we test whether large lottery jackpots will reduce the contribution activity of crowdfunders. This is so because large jackpots will divert at least some crowdfunders to satisfy their sensation seeking needs by playing the lottery. Additionally, lottery is an ideal repeated natural experiment because lottery jackpots are randomly won and the pot balloons in a series of draws with no winners. Therefore, it is difficult to find the negative relationship between lottery jackpots and bidding if such correlations were merely spurious.

To examine the relationship between lottery jackpots and crowdfunding contributions, this paper employs different datasets, specifications, and strategies, which are summarized as follows. First, we use all bidding activities of investors on Prosper Marketplace, one of the largest peerto-peer lending marketplaces in the U.S., between January 1st, 2007 and December 18th, 2010. Our findings indicate that doubling the combined jackpot size of Powerball and Mega Millions is associated with a decrease of $11.2 \%(8.2 \%)$ in bidding volume in dollars (total number of bids) of individual lenders. Additionally, the substitution effect is stronger for those days coinciding with large jackpots; when the jackpot size is in the top quartile distribution, the bidding volume (total number of bids) by individual lenders is lower by $18.2 \%$ (14.2\%) compared with the bottom quartile.

Second, To further rule out unobserved factors influencing both peer-to-peer bidding and lottery jackpots, we separately use the lottery jackpots in the U.S. multi-state lotteries Powerball and Mega Millions. Powerball and Mega Millions have similar rules, are available for purchase in almost similar jurisdictions, and offer jackpots of similar average sizes. Despite the statistical observation that Powerball and Mega Millions are uncorrelated with each other, we still find similar relationships separately between each lottery and crowdfunding contributions. Conceiving an alternative explanation based on the relationship of jackpot size and bidding activity is even more implausible when that explanation must justify why Mega Millions and Powerball jackpots are separately correlated with bidding activity but not with each other.

Finally, instead of focusing on multi-state lotteries of Powerball and Mega Millions, we focus on two state-level lotteries of California and Texas, typically among the largest state lotteries, and find supporting evidence for the sample of residents in California and Texas. We also perform several falsification tests to further rule out the possibility of spurious correlations. First, jackpot of state lotteries in California (Texas) is not associated with bidding activity of individuals residing outside of California (Texas). Second, we find that institutional investors' lending activity is not correlated with multi-state lotteries. This is consistent with the notion that sensation-seeking is less likely to be an important motivation among institutional investors.

We contribute to the studies that explore crowdfunders' motivations. Prior studies emphasize the role of intrinsic and extrinsic motivations, including the prospect of a reward, support and access to innovative products before others, recognition from others, promotion of their 
image and social reputation, and altruism (Colombo, Franzoni, and Rossi-Lamastra, 2015b; Giudici, Guerini, and Rossi-Lamastra, 2018; Boudreau, Jeppesen, Reichstein, and Rullani, 2017; Daskalakis and Yue, 2017). To this list, we introduce the sensation seeking motivation, that is a basic personality trait defined as "the seeking of varied, novel, complex, and intense sensations and experiences, and the willingness to take physical, social, legal, and financial risks for the sake of such experience" (Zuckerman, 1994). We contribute to the literature that seeks to identify the instances in which sensation-seeking influences investors' decisions (Barber, Lee, Liu, and Odean, 2008; Gao and Lin, 2014; Dorn, Dorn, and Sengmueller, 2014; Liao, 2017). These studies focus on trading activity of investors in the stock market, and find evidence consistent with gambling motivation of investors. We extend this line of evidence in the new institutional setting of peer-to-peer lending, which is remarkably different from the stock market in terms of information disclosure and skewness of financial payoffs.

\section{Related Literature}

\section{$2.1 \quad$ Peer-to-peer lending}

Crowdfunding is an umbrella term that encompasses distinct, yet evolving, models of fundraising from crowds: reward-based crowdfunding, equity based crowdfunding, donation based crowdfunding, lending based crowdfunding, and initial coin offering. Lending based crowdfunding (also known as, peer to peer, direct, or marketplace lending) is distinguished from other models by directly connecting multitude of lenders to borrowers who are posting loans through an online platform. As an innovation empowered by technology in the finance industry, peer to peer lending is a direct alternative to banks, securing loans for many borrowers who might not have been able to obtain loans from banks. ${ }^{2}$ While peer to peer lending share of the loan market is small, in some segment-countries these platforms are growing rapidly and challenging incumbent sources of loan origination such as banks. In 2017, business lending by U.K. crowdfunding platforms amounted to almost $30 \%$ of new loans to small businesses. ${ }^{3}$

Peer to peer lending literature has examined the lending decisions crowds make and how it shapes funding outcomes of listed loans. To explore how crowds overcome information asymmetries and potential moral hazards in screening loans, researchers have highlighted the role of quality signals and information disclosures (Iyer, Khwaja, Luttmer, and Shue, 2015). Borrowers can signal privately low default risk by posting low reserve interest rates (Kawai, Onishi, and

\footnotetext{
${ }^{2}$ Despite being creditworthy, some businesses are unable to obtain a loan through traditional channels and in turn, use crowdfunding. For instance, A fifth of borrowers in the Funding Circle believe they would not have been able to secure external finance in the absence of Funding Circle. https://static.fundingcircle.com/ files/uk/information-packs/small-business-big-impact-cebr-report-315de033.pdf

${ }^{3}$ https://www.jbs.cam.ac.uk/fileadmin/user_upload/research/centres/alternative-finance/ downloads/2018-5th-uk-alternative-finance-industry-report.pdf
} 
Uetake, 2014). Freedman and Jin (2017) find a positive signaling effect of bidding on friends' loan listings, especially pronounced among borrowers with lower credit grades. Similarly, having friends with high credit quality help prospective borrowers to fundraise successfully more often, to face lower interest rate, and to default less (Lin, Prabhala, and Viswanathan, 2013). Hildebrand, Puri, and Rocholl (2016) use a policy change in Prosper platform that changes the group leaders' incentive by discontinuing the payment of origination rewards (i.e. group leaders are no longer paid to create volume), thereby making group leaders less aggressive in bidding. Well-funded borrowers can also benefit from information cascades and attract more funding (Zhang and Liu, 2012; Herzenstein, Dholakia, and Andrews, 2011). Lenders favor borrowers that are socially, culturally, and geographically proximate to themselves (Galak, Small, and Stephen, 2011; Lin and Viswanathan, 2015; Burtch, Ghose, and Wattal, 2014). In addition to these factors, voluntary, unverified (and often unverifiable) disclosures (i.e. soft information such as descriptions about the loan purpose or identity claims) influence lenders' decisions. For example, the number of fundraising bids increases when a prospective borrower has disclosed information on the purpose of the loan, an explanation for poor credit grade, and a picture (Michels, 2012). Judging from profile pictures in the loan listings, lenders have an irrational bias towards attractive photographs (Ravina, 2012) and conversely, lenders benefit from biasing towards trustworthy faces (Pope and Sydnor, 2011).

Related literature has also tied the local availability of credit to lending outcomes. Ramcharan and Crowe (2013) find that one standard deviation decline in house prices within a state during the recent housing crisis is associated with higher rates of loans compared with those of otherwise-matched borrowers. Butler, Cornaggia, and Gurun (2016) find that borrowers residing in areas with good access to bank finance request loans with lower interest rates, and this effect is more pronounced for borrowers seeking risky or small loans. Thus, both lenders and borrowers' geographical location influence their decisions.

\subsection{What Motivates Crowdfunders to Contribute?}

Scholars have investigated the question of what motivates the backers and supporters in crowdfunding. ${ }^{4}$ Broadly, inspired by the framework of Ryan and Deci (2000), the backers' decision to contribute to crowdfunding incorporates aspects of both (i) extrinsic motivations present in traditional investment decision making (e.g. profit seeking or obtaining rewards) and (ii) intrinsic motivations typically present in charitable and prosocial contexts (e.g. altruism). Below we elaborate on these motivations.

Besides offering tangible rewards or interest payments to backers, crowdfunding campaigns often involve the pre-purchase of a product (Cholakova and Clarysse, 2015), often an innovative

\footnotetext{
${ }^{4}$ We don't overview the motivation of entrepreneurs that choose crowdfunding as their preferred source of financing. See Table 1 in Moritz and Block (2016).
} 
product at a discounted price. For instance, in lending based crowdfunding, Pierrakis and Collins (2013) were first to survey lenders and found that financial return is the main motivation behind individuals' decision to lend money to businesses; Ninety-five per cent of all surveyed lenders responded that the interest rate is important or very important. In this sense, backers expect profit, reciprocity (Colombo et al., 2015b), or recognition from others in return for their contributions (Bretschneider and Leimeister, 2017). There are intrinsic motivations that backers pursue; we cite a select few of these drivers (in no particular order): (1) helping others: backers want a certain project to be realized and act pro-socially (Giudici et al., 2018); (2) liking motive: backers like a certain venture and enjoy satisfaction from observing it realize and succeed, specially they enjoy supporting the cause (Cholakova and Clarysse, 2015); (3) image motive and sense of community motive: backers want to be liked or well-regarded by others and desire to be part of a community (Gerber and Hui, 2013); (4) identification motive: backers identify with founding teams or project goals (Boudreau et al., 2017).

Among the intrinsic motivations, there is some evidence that fun, entertainment, and novelty play a role in motivating crowdfunders. Berglin and Strandberg (2013) conducted survey of backers and reported that backers express fun as a relevant motive for their contribution, and interestingly, those crowdfunders that indicated fun as their strong reason for participating also tended to make smaller investments (p. 24). Ryu and Kim (2016) report survey evidence that among other factors, crowdfunders decide to support the project because it is fun to do so, and they find the act of participating appealing, enjoyable, and pleasurable. Finally, Daskalakis and Yue (2017) survey crowdfunders in Germany, Spain, and Poland about their motivations and report that "interest and excitement" is ranked as the second most important motivation, following financial returns as the number one reason to participate in peer to peer lending. These authors note that rankings are based on mean scores, but these differences in importance are not statistically significant from each other. ${ }^{5}$ Overall, using only survey evidence researchers have identified the role of "having fun" as one of the underlying motivations behind backers' contributions. Our study builds on these observations, but it is not suffering from methodological issues often associated with surveys and asking respondents explicitly about their motivations (for a review, see Nosek et al. (2011)); that is, we rely on methods that are not direct, intentional self-assessments.

\subsection{Gambling and Participating in Financial Markets}

A large portion of gamblers engage in gambling for fun, excitement, and sensation seeking (Binde, 2009). Sensation seeking is a personality trait that involves volunteering for risky activities, primarily to seek thrill and adventure from novel stimuli (Zuckerman, 1994). Horvath

\footnotetext{
${ }^{5}$ Daskalakis and Yue (2017) note that "interest and excitement" is the highest rated motivation for investors via equity crowdfunding, followed by increased diversification, higher returns, and disappointment in traditional means of investment.
} 
and Zuckerman (1993) note that sensation seeking is related to risky behavior in many domains, including gambling and financial risk taking. Below, we overview the emerging research that supports that active and speculative trading typically occurs because of sensation seeking (note that clearly investors don't only trade for sensation seeking). ${ }^{6}$

A growing body of research has identified sensation seeking and gambling as a motivation to participate in trading and investing (Barberis and Huang, 2008; Kumar, 2009; Grinblatt and Keloharju, 2009). Kumar (2009) provides coarse results that the demand for lottery-type stocks (i.e. low-priced stocks with high idiosyncratic volatility and high idiosyncratic skewness) is higher in states with local economic conditions conducive of gambling behavior (higher per capita lottery expenditures). ${ }^{7}$ More direct evidence on gambling motivated investment decisions come from survey of investors. Hoffmann (2007) surveyed Dutch investors and found that the second most important reason for investing is because investors find it a nice free-time activity (the first reason is the potential for financial gain). Dorn and Sengmueller (2009) directly survey clients of a German broker and find that trading intensity (portfolio turnover) varies based on the self-reported enjoyment of investing and gambling. Grinblatt and Keloharju (2009) use the number of automobile speeding convictions as a measure of sensation seeking and find that investors, who are sensation seekers, trade more frequently. Similarly, Cox, Kamolsareeratana, and Kouwenberg (2018) ask Dutch investors if they consider "the fun or the challenge of it" as one of their investment goals. These scholars report that gambling motives can explain a substantial part of individual investors' speculative trading behavior.

To overcome methodological issues associated with self-reported assessments and preference for sensation seeking, scholars have used other methods to link gambling motivations to the speculative stock market activity. Barber et al. (2008) showed that introducing legalized gambling sponsored by Taiwanese government reduced turnover on the stock market by about one-fourth. Gao and Lin (2014) demonstrated that during periods with high lottery jackpot, stock market trading volume in lottery-type stocks decreased. Similarly, Dorn et al. (2014) document a negative relationship between U.S. multistate lotteries and small trades in the U.S. stock market; Additionally, their study finds that during weeks with larger lottery prizes, discount brokerage clients in California and Germany are less likely to trade. Liao (2017) found that following Casino openings in the United States, portfolio risk taking increased among investors with demographic propensities associated with gambling. In sum, there is a well-established substitution effect between lotteries and risk-taking in the stock market. ${ }^{8}$ We extend these studies to the context of peer-to-peer lending.

\footnotetext{
${ }^{6}$ Raylu and Oei (2002) review the sensation seeking literature on gambling (p. 1020)

${ }^{7}$ Kumar (2009) found that purchase of lottery-stock increases in regions of the US with lower income, higher unemployment rate, minority group race/ethnicity, Catholic, less educated, and younger.

${ }^{8}$ Cookson (2018) found that the introduction of lottery-linked savings accounts in Nebraska was associated with a $7 \%-15 \%$ decline in casino expenditure.
} 


\section{Hypothesis Development: Crowdfunding as Gambling}

We argue that at least some individuals substitute between gambling inside and outside the peer-to-peer lending markets, specifically between playing the lottery and participating in the peer-to-peer lending market. This is so because sensation seeking is one of the underlying motivations for some peer-to-peer lenders. The thrill of winning a large jackpot lottery, perhaps intensified by advertising and media coverage around this event, substitutes some individual lenders' desire of sensation-seeking to participate in the peer-to-peer markets, decreasing their bidding activity.

The substitution hypothesis between playing the lottery and participating in peer-to-peer lending is based on the potential role of sensation-seeking in lenders' motivation. Playing the lottery and lending on the peer-to-peer markets are distinctively different activities, including the required capital to participate and the level of patience before realizing the returns from lending. Despite these differences, they can produce the same thrill and excitement for those investors who are sensation seekers. Bidding for different loans not only involves risk taking by taking new bets, but also contains elements of novelty and variety. Adding a new loan in the investor's portfolio and therefore changing the composition of their portfolio can provide the desired novelty and variety of experiences that sensation seekers search for. Thus, we suggest that some lenders will substitute between playing the lottery and lending in peer to peer markets to the extent that sensation-seeking motivation drives their behavior.

When the jackpots are large, their magnitude draws a lot of crowds' attention. ${ }^{9}$ Given the strong element of fun and entertainment inherent in playing the lottery (Oster, 2004), and the notable, but low, chance of winning and getting extremely rich, their influence on investors' attention can take away from their activity in other financial markets (Gao and Lin, 2014; Dorn et al., 2014; Gao and Lin, 2014), including bidding on newly listed loans. Conversely, when jackpots are relatively small, this might be a scenario that bidding on certain loans might appear more attractive.

We focus on lottery, as a form of gambling, because of several useful institutional features. Lotteries are largely available and frequently played, sometimes the numbers are drawn twice per week. Lottery jackpots are randomly generated and additionally, whenever the lottery is not won, the pot rolls over to the subsequent pot and large jackpots form. To illustrate, the correlation between two of the largest U.S. lotteries, Mega Millions and Powerball jackpots, is only 0.05 . Therefore, we leverage the repeated natural experiment of lottery and test whether the sensation-seeking consumed by participating in lottery of large jackpots relatively substitutes away from participating in the peer-to-peer lending market.

\footnotetext{
${ }^{9}$ Barnes, Welte, Tidwell, and Hoffman (2010) show that $49 \%$ of the U.S. citizens regularly buy lottery tickets at least once in a year. Surveys from Gallup also point out these participation levels are stable during the 1990-2015 period.
} 
Hypothesis 1. There is a substitution effect between bidding activity and lottery participation when the lottery jackpot is large.

\section{Data}

We assemble data from four different sources: 1) The multi-state lotteries: Powerball and Mega Millions; 2) State lotteries in California, Texas, New York, and Florida; 3) Prosper Marketplace; and 4) Kickstarter. Below we explain each data source and the institutional features relevant to our study.

\subsection{Prosper Marketplace}

Data from Prosper.com include all loan listings and all investors' bids between January 1, 2007 and December 18, 2010. Prosper, among the first U.S. peer to peer lending marketplaces, started its operations on November 9, 2005, and the value of loans originated on this platform has surpassed $\$ 14$ billion as of March 2019. ${ }^{10}$ Over time, the dollar value of loans originated on crowdlending platforms reached to levels that attracted more investors' attention and media. The growth in legitimacy of this emerging industry partly is attributed to improved policies such as disclosing credit risk. For instance, on February 12, 2007, Prosper started to disallow borrowers with credit scores below 520, and to inform lenders about delinquency amounts (for details see Appendix, Table A1). Prior research has also used Prosper dataset to explore other issues such as home bias, herding, and design of market mechanisms (Zhang and Liu, 2012; Lin and Viswanathan, 2015; Wei and Lin, 2016).

Our analysis begins from January 1, 2007 given the notable growth of the platform activity starting this period. To illustrate, while dollar value of total listings (funded loans) on Prosper in the first quarter of 2006 was $\$ 30$ million ( $\$ 1.6$ million), this number from the first quarter of 2007 was $\$ 263.3$ million ( $\$ 20$ million). Relatedly, the dollar value of funded loans from the last quarter of 2006 to the first quarter of 2007 showed $72 \%$ growth.

The analysis ends on December 18, 2010 for the following reason. Until December 18, 2010, interest rates on loans were set according to Dutch auction process: Borrowers would specify the amount of loan and the maximum interest rate they were willing to pay; then, lenders would bid on those loan listings by submitting the amount they would like to fund and the minimum interest rate. Prosper replaced the Dutch auction process with a new system according to which the platform chose the final interest rates based on a proprietary formula that would also include borrowers' credit risk. Therefore, as soon as a loan is fully funded, that loan is removed and

\footnotetext{
${ }^{10}$ Check https://www.prosper.com/invest for details.
} 
borrowers cannot bid more (to compete on the interest rate) - total value of bids made on a listing would never pass the listing value.

While we have chosen a period with relatively lower experimentation and policy change by the platform (given the nascent business model of peer-to-peer lending in this period), there is a data gap in our sample period. Prosper suspended operations from October 19, 2008 to July 14, 2009 to register with the SEC to create a secondary marketplace. The re-opening, however, was conditional on obtaining approval from each state to allow lenders to invest in loans listed on Prosper. On July 14, 2009, lenders from 14 states, including California with the highest number of lenders and borrowers active on the platform, were able to lend on Prosper. Table A2 presents the timeline of approvals from additional states. It is noteworthy to mention that a lender from any approved state can bid on any listing requested by borrowers from any other approved state in the US.

Finally, we limit the analysis to all bids from the states whose lenders could participate in at least one of the two multi-state lotteries, Powerball and Mega Millions, at the time of the analysis. Table A3 lists when Powerball and Mega Millions got introduced in each US state. Applying this filter reduces the sample size of all bids by $9.5 \%$, and the final sample includes $6,524,540$ bids on 314,408 loan listings.

\subsection{Kickstarter}

The second source of crowdfunding data comes from Kickstarter. Kickstarter is among the largest U.S. crowdfunding platforms, that was established in 2009 and as of March 19, 2019, the total dollars committed to successful campaigns on the platform has reached to about $\$ 4.2$ billion. ${ }^{11}$ Kickstarter only hosts reward-based campaigns (Colombo et al., 2015b): backers contribute to campaigns in expectations of receiving some form of reward including, but not limited to, a product, participating in a concert, an acknowledgment in the film credits, or a symbolic token of appreciation. Additionally, campaigns follow an all-or-nothing fundraising model: campaign organizers receive the pledges from the crowd only if their campaign reaches/exceeds its funding goal, which can only be set at the beginning of the campaign.

Data from Kickstarter include all contributions (pledges) for Kickstarter campaigns, starting from September 18, 2012 to May 20, 2013. During this period, 1,309,295 backers contributed to 16,042 campaigns.

\footnotetext{
${ }^{11}$ See https://www.kickstarter.com/help/stats for details.
} 


\subsection{Powerball and Mega Millions}

Powerball and Mega Millions are the biggest lotteries in the US. ${ }^{12}$ As of March, 2019, 44 states offer both lotteries. Drawings for Powerball are held on Wednesdays and Saturdays at 10:59 p.m. Eastern Time, and drawings for Mega Millions are held on Tuesdays and Fridays at 11 p.m. Eastern Time. The largest Powerball jackpot in history was $\$ 1.586$ billion for the January 13, 2016 drawing, and the largest Mega Millions jackpot in history was $\$ 1.537$ billion for the October 13, 2018 drawing. The numbers that determine who wins the lottery jackpots are randomly drawn. The correlation between Powerball and Mega Millions lotteries is only 0.05 in our sample. When a lottery has no winner, the pot is rolled over into the subsequent jackpot. When a series of lottery jackpots are not won, the pot becomes large and attracts more attention from lottery players and the media.

The official website at https://www.megamillions.com lists the complete jackpot history of Mega Millions for the past 10 years. Similarly, Powerball website (https://www . powerball. com) provides a complete record of all drawings and winning numbers since 2000, but not the jackpot history publicly. Lottery organizers, however, provide jackpot histories of both lotteries upon request. Additionally, there are publicly available resources with the complete history of both lotteries. ${ }^{13}$ At the beginning of our sample period in 2007, the coverage of Powerball (30 states) was considerably larger than the coverage of Mega Millions (12 states). Table A3 presents the timeline related to the introduction of each game. In our sample, the average of Powerball jackpots ( $\$ 70.0$ million) is slightly larger than the average of Mega Millions jackpots (\$67.4 million), and the average size of the combined jackpot is also $\$ 137.3$ million.

\subsection{State lotteries}

In addition to multi-state lotteries (Powerball and Mega Millions), we use data from state lotteries. More specifically, we focus on four states of California, Texas, New York, and Florida. In addition to representing large economies, these states have relatively large state lotteries.

California's SuperLotto is the biggest state lottery in the U.S. and SuperLotto's drawings are held every Wednesday and Saturday. Lotto Texas, official lottery of Texas, has the largest average jackpot size in our sample with $\$ 23.7$ million. Lotto Texas drawings are held on Wednesday and Saturday evenings. Formed in 1991, Lotto Texas is the youngest of these four state lotteries. New York Lotto and Florida lottery, with an average jackpot size of $\$ 12.2$ million and $\$ 12.6$ million respectively, are considerably smaller in comparison to California and Texas lotteries. The drawings of both New York and Florida lotteries are held on Wednesday and

\footnotetext{
${ }^{12}$ https://www.foxbusiness.com/features/top-5-biggest-lottery-jackpots

$13 \mathrm{http}: / /$ www.lottofactor.com/ is a comprehensive and free of charge resource that provides the complete jackpot history of all multi-state and single state lotteries in the U.S.
} 
Saturday.

The official websites of the California, Texas, and Florida lotteries provide the full or partial jackpot histories. ${ }^{14}$ Access to data for New York Lotto is possible upon request from the game organizers. Note that the website http://www. lottofactor.com offers the jackpot histories of all four state lotteries.

\section{Method}

Following previous studies that explore the link between lotteries and financial decision making (Dorn et al., 2014), our baseline specification is as follows:

$$
\log \left(B_{t}\right)=\alpha+\beta \log \left(J_{t}\right)+\Lambda C_{t}+\varepsilon_{t}
$$

Where $B_{t}$ refers to two related dependent variables: (1) The total amount of all contributions made on all available listed loans on day $t$; (2) The number of bids made by individual lenders made on all available listed loans on day $t . \quad J_{t}$ is the combined jackpot from Powerball and Mega Millions lotteries on day $t$. $C_{t}$ is a vector of control variables. Lastly, $\varepsilon_{t}$ is the error term. We fit an ordinary least squared (OLS) model to estimate the parameter of interest $\beta$. All OLS regressions in the analysis have heteroscedasticity robust standard errors. It is noteworthy that lottery jackpot is a repeated natural experiment because lottery jackpots are won randomly and the pot increases in size with a series of drawings with no winners. Therefore, jackpot size is unlikely to be related to other unobserved factors such as the economic condition (usually present in the error term denoted by $\varepsilon_{t}$ that could have biased the coefficient on $\beta$ ).

To alleviate concerns related non-stationary time-series of our variables we perform the Augmented Dickey-Fuller test and the Phillips-Perron test to check if our variables have a unit root. The results from both tests confirm that our variables are stationary. The null hypothesis of a unit root is rejected at a confidence level below 1\%. We also conduct Durbin-Watson and Breusch-Godfrey tests to check whether residuals are autocorrelated or not. Test results confirm that our regression residuals are correlated. By checking the regression residuals, we find out that autocorrelation seems to be strong at the first lag, but quickly weakens after the third lag. To deal with serial correlation for the rest of our analysis, we estimate Newey and West (1987) heteroscedasticity and autocorrelation consistent (HAC) standard errors allowing for serial correlation up to five lags. In the literature, common practice for determining the number of lags is to take the integer part of $n^{1 / 4}$ or the integer part of $4(n / 100)^{2 / 9}$, which give for our sample (with 1,189 observations) 5 and 6 respectively (Wooldridge, 2015). In unreported

\footnotetext{
${ }^{14}$ Websites respectively: https://www.calottery.com; https://www.txlottery.org; http://www.flalottery.com.
} 
robustness checks, we rerun all regressions with Newey-West standard errors allowing for serial correlation up to 30 lags (i.e. approximately one month), and confirm that all of our results hold after these tests.

Table A4 presents the definitions of all variables used in this study; we explicate the reasoning for our choice of control variables, $C_{t}$. We control for Total listing, that is the total sum of all the funding needed to fully fund all loans listed on the platform on a given day. This variable proxies for the total demand for credit on any given day. To control for the competition among bidders, we include the variable Share of winning bids, that is the fraction of bids that eventually funded the loan (i.e. winning bid) to the overall bids. Note that a bid can only be in one of the following categories: Winning, partially participating, outbid, and withdrawn bid. To control for the attractiveness of loan returns, we control for Weighted average lender rate. This variable is based on "spot lender rate" (i.e. the interest rate lenders would have received on a loan if the loan was finalized and issued on that day) given the weights equal to the loan size. Thus, Weighted average lender rate is the loan-size weighted "spot lender rate". To control for the potential role of U.S. equity stock market in attracting investors' dollars away from peer-to-peer lending market (or when investors are looking for attractive alternatives to the stock market), we include $S \mathscr{B} P 500$ Return, that is the value-weighted return on the S\&P 500 index. Finally, our specifications consider the growing popularity of crowdfunding platforms such as Prosper and include a linear time trend Date. Finally, we include dummy variables for day of the week, and month of the year. For instance, lenders might have more free time on weekends to spend on assessing loans.

\section{Results}

Table 1 provides the summary statistics of variables in this study. The mean Bid size for individual lenders is about $\$ 75$, and the fully funded Loan size is on average about $\$ 6,000$. The dollar value of all bids on average is about $\$ 500$ million, while dollar value of all loans listed (but some are not fully funded) is about $\$ 2.5$ billion. Only about $10 \%$ of listed loans (i.e. 30,685 ) were successfully funded; $87.4 \%$ of the listed loans either failed to get enough funding or were withdrawn by borrowers' request (who perhaps anticipated failure before the listing expired); and the remaining $2.8 \%$ of listed loans were cancelled by Prosper. Institutional investors comprise less than $1 \%$ of all bids. The sum of total dollar value of the institutional investors' bids amount to $\$ 6.6$ million (1.3\% of all bids), and their average bid size is $\$ 168$. We present the results of multivariate analysis in the following subsections. 


\subsection{Multi-state Lotteries and Bidding in Prosper}

Table 2 presents the regression results using specification 1. Columns (1) and (2) reports OLS regressions predicting bid amount made by all individual investors, based on jackpots in Powerball and Mega Millions, respectively; in terms of economic magnitude, doubling the jackpot is associated with $8.8 \%$ and $5.2 \%$, respectively, decline in total sum of bidding amount on a given day. The correlation between these multi-state jackpots is very low (0.05) and thus, it is less likely that spurious correlations or omitted variables varying with one of the jackpots can explain the results presented in Columns (1) and (2). Powerball and Mega Millions have similar rules, and offer jackpots of similar average sizes. Despite the statistical observation that Powerball and Mega Millions are uncorrelated with each other, we still find similar evidence across each multi-state lotteries separately. Conceiving an alternative explanation based on the relationship of jackpot size in each game and bidding activity is even more implausible when that explanation must justify why Mega Millions and Powerball jackpots are separately correlated with bidding activity but not with each other.

Column (3) considers the sum of jackpots in Powerball and Mega Millions as the main theoretical construct. We create this variable because are interested in the overall effect of playing the lottery (and not a particular jackpot). Doubling Powerball+Mega Millions is associated with about $11 \%$ decline in the total sum of bids by all individual investors.

Column (4) of Table 2 reports the results of specification 1 using Newey-West standard errors. We again obtain similar results, supporting Hypothesis 1.

In Column (5) of Table 2, we consider the possibility of nonlinear jackpot effects by including dummy variables for jackpot quartiles. Jackpot quartiles are created by dividing lottery jackpots (Powerball+ Mega Millions) into four different groups based on their size relative to the entire sample period. Results indicate that only during those days with jackpots in the 4 th quartile size distribution compared with the bottom quartile, bid amount decreases significantly by $18.4 \%$. In Column (6), we perform a similar analysis by including a large jackpot dummy, that is equal one if the jackpots are in the top decile of Powerball+Mega Millions size distribution. Again, we find similar results.

In subsequent columns we report several additional robustness tests. First, in Column (7) of Table 2, we include the detrended jackpot variable and repeat our analysis. To detrend the Powerball+ Mega Millions variable, we estimate a linear regressions of the logarithm of the combined Powerball and Mega Millions jackpots on a constant and a linear time trend. Second, Column (8) presents the regression coefficients when we include the combined jackpots of Powerball and Mega Millions jackpots without log-transformation. Third, Columns (9) and (10) present regression results with a new dependent variable: the total number of bids made by individual investors on a day (Bid number). Doubling Powerball+ Mega Millions is associated 
with $8.2 \%$ decline in Bid number. In unreported robustness checks, we rerun all regressions with Newey-West standard errors allowing for serial correlation up to 30 lags, and we confirm that the coefficients on Powerball+ Mega Millions from the Table 2 remains statistically significant.

In Table 3, we modify our specifications and include lagged dependent variables (LDV) as an alternative way to deal with autocorrelation. Some researchers view autocorrelation as a technical violation of the OLS assumptions that leads to incorrect estimation of the standard errors. ${ }^{15}$ We repeat all of our main analyses after including one or two lags of the dependent variable and present the results in Table 3. Except the first two specifications (Columns (1) and (2) of Table 3) that replicate the previous Table 2, the rest of the specifications include LDVs. Including the first two lags of the dependent variable eliminates serial correlation, but BreuschGodfrey and Durbin's alternative test results show that there may still be serial correlation at higher lags. Wooldridge (2015) recommends the use of Newey-West standard errors in models with lagged dependent variables when researchers are not sure that the inclusion of LDV fully removes autocorrelation. Following this recommendation, we use Newey-West standard errors in our models with lagged dependent variables. It appears that the first lag of the dependent variable has a significant impact in all specifications in Table 3. Additionally, the coefficients on jackpots in Columns (3)-(6) decrease in economic magnitude approximately by half compared with benchmark results in Columns (1) and (2). Similar observations are in order for Bid number in Columns (7)-(10). These observations further increase our confidence that our results are robust to correcting for autocorrelation. In additional unreported robustness checks, we rerun all the regressions with LDV in Table 3 using Newey-West standard errors allowing for serial correlation up to 30 lags and obtain similar results.

\subsubsection{Do Large Lottery Jackpots Influence Institutional Investors' Lending Activ- ity?}

We have limited our discussion to the lending activity of the individual investors because it is unlikely that institutional investors are driven at the same level as individuals by sensationseeking motivations (rather, we expect institutional investors to be mostly concerned with financial returns). We explore the veracity of such claim. Note that the majority of the lenders in our sample are individual investors - only $0.6 \%$ of all bids in our main sample are made

\footnotetext{
${ }^{15}$ Other researchers, however, view autocorrelation more suspiciously and believe it is a potential sign of theoretical misspecification. LDV are often added to specifications to deal with autocorrelation, and adding a lagged dependent variable could remove serial correlation. Achen (2000) argues that including LDV in regressions can lead to underestimating the effect of the regressors if there is autocorrelation in the error term. When there is serial correlation in errors, Achen (2000) claims that LDV should not be included in the regression even if the LDV is actually part of the data-generating process. Keele and Kelly (2006), and Wilkins (2018) argue that excluding LDV would induce an omitted variable bias when the LDV are part of the datagenerating process. In certain cases, this bias can be high, and thus, these authors recommend researchers to include LDVs. Our conclusion from reading this literature is the following. In general, researchers may worry about adding LDV to their specifications because including LDV lead to smaller coefficient estimates for independent variables. Moreover, adding LDV does not guarantee to eliminate the serial correlation in errors.
} 
by institutional investors and dollar value of all bids in our main sample is $\$ 494$ million while dollar value of all bids made by institutional investors is $\$ 6.6$ million (institutional investors' bids make up $1.3 \%$ of the total bidding volume in dollars). Note that the size of the average bid by institutional lenders is $\$ 168$, which is more than twice the size of the average bid by individual lenders.

Table 4 examines the relationship between lottery jackpots and institutional investors' lending activity. While in Column (1) we report a significantly negative relationship between Powerball+ Mega Millions and the bidding amount by institutional investors, this finding is not robust to including the bidding amount of individual investors (Columns (2)-(3)). To explore further, we create a new dependent variable, Share of institutional investor bids, that is equal to the fraction of bidding volume by institutional investors over the total bidding volume on a day. We again fail to find significant relationship between Powerball+Mega Millions and Share of institutional investor bids. We don't find significant coefficients on Powerball+ Mega Millions in the model specifications with control variable $\log$ (Bid amount) in Table 4 . These results support our view about the differences between institutional and individual lenders active in this market.

\subsubsection{Are the Results Robust If the Unit of Analysis Is Listing or Bid Level?}

Unlike the previous sections that presented the daily aggregate of all bids as the level of analysis, this section focuses on two new units of analyses. Because the aggregate level analyses doesn't consider the heterogeneity of loan listings and bidders, we perform two additional set of analyses by changing the unit of analyses: (1) We aggregate all bids for a listing on each day into one observation (listing-day level). this specification controls for unobserved heterogeneity regarding loans; Since the loans are usually open for a short period of time, it is unlikely that loan characteristics vary across time for each listing; (2) To control for bidder heterogeneity (by including bidder fixed effects), we repeat our analysis at bid level. Additionally, in this analysis we control for listing characteristics. The results of both these sets are discussed below.

Table 5 present the regression results based on listing-day level. The dependent variable in Columns (1)-(6) is $\log$ (Bid amount), defined as the natural logarithm of the total sum of bidding volume in US dollar by all lenders on a particular loan listing on a given day. The dependent variable in Columns (7)-(10) is Log(Bid number), defined as the natural logarithm of the total sum of the number of bids by all lenders on a particular loan listing on a given day. The results confirm our previous conclusions in Table 2: larger jackpot are associated with fewer and smaller bids. In Column (6) we investigate whether the effect is different for riskier borrowers (proxied by borrower's debt-to-income ratio). The result shows that substitution effect is stronger for biddings in listings with higher risk. 
Table 6 present the results based on bid level. The dependent variable in all models is natural logarithm of an individual bid. In column (3) and (4) we also control for listing characteristics (listing size, borrower's debt-to-income ratio). In all models we include the bidder fixed-effect, which provides within bidder estimates. The results are again consistent with our hypothesis and show that larger jackpots are associated with smaller bids. In unreported analyses we also performed an analysis at bidder-day level by aggregating all bids from a bidder on a given day. The results are similar and available upon request.

\subsection{State Lotteries and Bidding in Prosper}

This section uses data from state lotteries instead of multi-state lotteries, Powerball and Mega Millions. More specifically, we focus on the state lotteries in the following four states: California, Texas, New York, and Florida. For each state, we only focus on the lending activity of residents in that focal state We selected these states for the following reasons. First, lenders from California, New York, and Texas have the highest number of bids in our sample $(24.8 \%$, $8.7 \%$, and $6.3 \%$ respectively); Lenders resident in Florida comprise only $2.1 \%$ of all bids. ${ }^{16}$ Such distribution reflects the fact that these four states have the highest gross domestic product in the US. Second, state lotteries are not large compared with multi-state lotteries, Powerball and Mega Millions. These four states have some of the biggest state lotteries in the U.S. (Table 1 presents descriptive statistics on the size of state loans). Finally, lenders from these four states are likely to represent different demographics.

To link state lotteries with lending activity in a state, we create several new dependent variables. To obtain Share of state bids, we divide the total sum of bids (in dollar terms) made by residents in that focal state over all bids in a day. Similarly, we calculate Share of state count as the fraction of the total count of bids made by residents in that focal state over all bids in a given day. For additional tests, we consider secular variations across time and create Normalized state count (bids) in two steps: First, we calculate the daily average of bidding count (amount in dollar terms) by all lenders over a month. Second, we compute Normalized state count (bids) on a day as the fraction of bidding count (volume in dollars) made by residents of the focal state over the corresponding result from the first step.

We will first focus on regression results from California (Table 7), whose average lottery jackpot size is among the highest across US; in California, the median lottery jackpot is $\$ 16$ million, the mean is $\$ 21.6$ million and the largest jackpot is $\$ 93$ million. Panel A of Table 7 show that in California, there is negative relationship between state lottery jackpot and the dependent variables: Share of California bids and Share of California count. For instance, the bids in California relative to all states decline by $5.4 \%$ on days when jackpots hit the top quartile of its distribution. In unreported robustness checks, we repeated the tests in Columns (1) and

\footnotetext{
${ }^{16}$ Borrowers' geographic location follows a similar distribution.
} 
(2) with two lags of the dependent variable and found that our results remain unchanged. We also included the raw jackpot value instead of the log jackpot and obtain similar results. It is noteworthy to mention our placebo tests (reported in Columns (6) and (7)) and find that California lottery jackpots are not influencing the lending activity of lenders who are not residents in California.

We present similar analysis for Texas (Panel B of Table 7), New York (Panel A of Table 8), and Florida (Panel B of Table 8). To briefly highlight the results from this set of analysis, it appears that lenders resident in Texas respond to the corresponding state lottery in substituting their lending activity, but the other two states (NY and FL) don't. One plausible explanation is related to the smaller size of NY and FL state lotteries. In California and Texas, the average lottery jackpot size is among the highest across US; in California (Texas), the median lottery jackpot is $\$ 16$ million ( $\$ 15$ million), the mean is $\$ 21.6$ million ( $\$ 23.7$ million) and the largest jackpot is $\$ 93$ million ( $\$ 97$ million). In comparison, the median lottery jackpot in New York (Florida) is $\$ 9.5$ million ( $\$ 9$ million), the mean is $\$ 12.2$ million ( $\$ 12.6$ million) and the maximum is $\$ 65$ million (\$52 million). Given that NY and FL jackpot is on average approximately half the size of Texas jackpot, we might not observe significant effects in NY and FL. To further explore the relevance of jackpot size, we combine the state lotteries and Powerball+ Mega Millions in NY and FL, respectively, and obtain statistically significant coefficients on the combined pot in regressions constructed similar to Table 8.

To summarize, to alleviate concerns over spurious correlations between multi-state lotteries and lending activity, we use data from state lotteries. It appears that we find support for Hypothesis 1 only in states with large jackpot sizes.

\subsection{Multi-state Lotteries and Contributions to Kickstarter}

We have so far considered lending activity in Prosper Marketplace, but it is unclear whether our findings on sensation-seeking motivation of investors generalize to other types of crowdfunding. To explore this question, we focus on one of the largest U.S. reward-based crowdfunding platform, Kickstarter. Reward-based crowdfunding is different from lending-based crowdfunding both in terms of institutional structure and the crowds' motivations. For example, Boudreau et al. (2017) argue that non-pecuniary motivations is the main drivers of contributors in rewardbased crowdfunding. Despite these differences, we explore whether sensation-seeking is one of the underlying motivations for supporters' contributions in reward-based crowdfunding. We have described the details of the sample in Section 4.2.

We present the results in Table 9. The dependent variable, Pledged, is the total sum of contributions to all campaigns in a given day. We also control for total demand by creating the variable Unfullfilled goal amount, that is the total sum of funding needed at a given day if all 
campaigns were to be fully funded. Note that we have made an assumption in our analysis: majority of the backers are from U.S. and are located in states that can purchase multi-state lottery tickets. This assumption is in line with studies that document home bias for crowdfunding (Lin and Viswanathan, 2015). The results presented in Table 9 are not strong enough to provide support for Hypothesis 1. We interpret this evidence to indicate that sensation-seeking motive is stronger among peer-to-peer lenders relative to that of backers in reward-based crowdfunding, whose objective might be more prosocial or simply pre-purchase of products.

Additionally, we argue that this non-result questions the validity of alternative explanations related attention-grabbing story: because large jackpots are widely advertised, individuals' attention is consumed by lottery, resulting in substitution hypothesis. To reiterate, if large jackpots only attracted the attention of individuals, then we would have expected significant results across both Kickstarter and Prosper. However, our results suggest this is not the case.

\section{Conclusion}

This paper argues that one underlying motivation for crowdfunders active in peer-to-peer lending markets is sensation-seeking. To empirically substantiate this argument, we investigate whether individuals participating in Prosper, one of the largest U.S. lending markets, reduce their lending activity when gambling in the form of playing the lottery becomes more attractive. The results indicate robust evidence across different samples in support of negative relationship between lottery jackpot size and contributions to peer-to-peer lending crowdfunding. We take these findings as evidence that playing the lottery satisfies crowdfunders' sensation-seeking desires.

We are not suggesting that all crowdfunding activity is purely motivated by gambling motives or this is the primary reason on the list of motivations for crowdfunders. However, we believe to some extent, some crowdfunders are sensation seekers, searching for novel and intense experiences just for fun and thrill. We also do not find any evidence that this behavior is economically irrational such that loans funded in periods of high jackpot size are similar in terms of default to those loans funded in periods of low jackpot size.

We are well-aware that peer-to-peer lending and playing the lottery have two very different financial return characteristics. The maximum interest rate on Prosper loans is $35 \%$, while maximum financial returns from playing the lottery can be extremely high, although the expected return on playing the lottery is always negative. Additionally, the size of the median bid by individual lenders is about $\$ 50$, but the cheapest lottery tickets cost $\$ 1$ and can increase depending on the selected options. We argue that, despite these differences, both activities can produce the same thrill and excitement for some lenders who are sensation seekers, and those 
lenders will substitute between playing the lottery and lending in peer-to-peer markets.

While we suggested that both playing the lottery and contributing to crowdfunding can generate the same underlying sensation-seeking, we have made the assumption that those who are in the crowdfunding market also are likely to buy lottery tickets. Given lack of direct survey evidence here, we present some initial demographic evidence. On the marketplace lending side, Adams, Dore, Greene, Mach, and Premo (2017) survey U.S. consumers, and find that about one-quarter of the consumers have some awareness of marketplace lending, and these customers are generally wealthier (income above $\$ 25,000$ ) and more educated (college degree). Turning to those participating in Powerball and Mega Millions lotteries, Barnes et al. (2010) find across two U.S. household surveys that about half of the U.S. citizens regularly buy lottery tickets at least once in a year. The Gallup surveys also find similar participation rates of about $50 \%$ into lottery. ${ }^{17}$ The Gallup survey from 2016 further indicates that higher-income (above $\$ 36,000$ ) and more educated Americans (college degree and postgraduate education) were more likely than lower-income and less-educated Americans to buy lottery tickets. ${ }^{18}$ Therefore, our assumption that some crowdfunders also buy lottery tickets, specially when the jackpot is relatively large, seems plausible based on the coarse demographics of crowdfunders with potential interest in buying lottery tickets.

Our study has implications for consequences of (multi-)state lotteries, that about half of Americans at least occasionally play. Given that states tout revenue from lotteries as supplementary funds towards important public causes such as education (e.g. in Florida), or environmental protection (e.g. in Colorado), our evidence on the substitution between playing the jackpot lottery and crowdfunding contributions indicates a warning siren. The role of lottery in solving state budget issues does involve tradeoffs, specially when politicians hail crowdfunding as one sustainable path towards funding innovation, filling the funding gap for small businesses, and even potentially helping individuals.

\footnotetext{
${ }^{17}$ https://news.gallup.com/poll/193874/half-americans-play-state-lotteries.aspx

${ }^{18}$ Note that the common conception of gamblers as lower-income and less-educated Americans is not also supported by Gallup studies from 1999, 2004, and 2007. https://news.gallup.com/poll/193874/half-americansplay-state-lotteries.aspx
} 


\section{References}

Achen, C. H., 2000. Why lagged dependent variables can suppress the explanatory power of other independent variables. In: Annual Meeting of the Political Methodology Section of the American Political Science Association, UCLA, vol. 20, pp. 07-2000.

Adams, R., Dore, T., Greene, C., Mach, T., Premo, J., 2017. Us consumers' awareness and use of market-place lending. Current Policy Perspectives .

Barber, B. M., Lee, Y.-T., Liu, Y.-J., Odean, T., 2008. Just how much do individual investors lose by trading? The Review of Financial Studies 22, 609-632.

Barberis, N., Huang, M., 2008. Stocks as lotteries: The implications of probability weighting for security prices. American Economic Review 98, 2066-2100.

Barnes, G. M., Welte, J. W., Tidwell, M.-C. O., Hoffman, J. H., 2010. Gambling on the lottery: Sociodemographic correlates across the lifespan. Journal of Gambling Studies 27, 575-586.

Belleflamme, P., Lambert, T., Schwienbacher, A., 2014. Crowdfunding: Tapping the right crowd. Journal of business venturing 29, 585-609.

Berglin, H., Strandberg, C., 2013. Leveraging customers as investors: The driving forces behind crowdfunding.

Binde, P., 2009. Gambling motivation and involvement: A review of social science research. Swedish National Institute of Public Health.

Block, J. H., Colombo, M. G., Cumming, D. J., Vismara, S., 2018. New players in entrepreneurial finance and why they are there. Small Business Economics 50, 239-250.

Boudreau, K., Jeppesen, L. B., Reichstein, T., Rullani, F., 2017. Entrepreneurial crowdfunding without private claims .

Bretschneider, U., Leimeister, J. M., 2017. Not just an ego-trip: Exploring backers' motivation for funding in incentive-based crowdfunding. The Journal of Strategic Information Systems $26,246-260$.

Burtch, G., Ghose, A., Wattal, S., 2014. Cultural differences and geography as determinants of online pro-social lending. Management Information Systems Quarterly 38, 773-794.

Butler, A. W., Cornaggia, J., Gurun, U. G., 2016. Do local capital market conditions affect consumers' borrowing decisions? Management Science 63, 4175-4187.

Cholakova, M., Clarysse, B., 2015. Does the possibility to make equity investments in crowdfunding projects crowd out reward-based investments? Entrepreneurship Theory and Practice $39,145-172$.

Colombo, M. G., Franzoni, C., Rossi-Lamastra, C., 2015a. Cash from the crowd. Science 348, $1201-1202$.

Colombo, M. G., Franzoni, C., Rossi-Lamastra, C., 2015b. Internal social capital and the attraction of early contributions in crowdfunding. Entrepreneurship Theory and Practice 39, $75-100$.

Cookson, J. A., 2018. When saving is gambling. Journal of Financial Economics 129, 24-45.

Cox, R., Kamolsareeratana, A., Kouwenberg, R., 2018. Gambling in the stock market: The motivations behind excessive and speculative trading. 
Cumming, D., Groh, A. P., 2018. Entrepreneurial finance: Unifying themes and future directions. Journal of Corporate Finance 50, 538-555.

Da Cruz, J. V., 2018. Beyond financing: crowdfunding as an informational mechanism. Journal of Business Venturing 33, 371-393.

Daskalakis, N., Yue, W., 2017. User's perceptions of motivations and risks in crowdfunding with financial returns, sSRN.

Dorn, A. J., Dorn, D., Sengmueller, P., 2014. Trading as gambling. Management Science 61, $2376-2393$.

Dorn, D., Sengmueller, P., 2009. Trading as entertainment? Management Science 55, 591-603.

Freedman, S., Jin, G. Z., 2017. The information value of online social networks: lessons from peer-to-peer lending. International Journal of Industrial Organization 51, 185-222.

Galak, J., Small, D., Stephen, A. T., 2011. Microfinance decision making: A field study of prosocial lending. Journal of Marketing Research 48, S130-S137.

Gao, X., Lin, T.-C., 2014. Do individual investors treat trading as a fun and exciting gambling activity? evidence from repeated natural experiments. The Review of Financial Studies 28, $2128-2166$.

Gerber, E. M., Hui, J., 2013. Crowdfunding: Motivations and deterrents for participation. ACM Transactions on Computer-Human Interaction (TOCHI) 20, 34.

Giudici, G., Guerini, M., Rossi-Lamastra, C., 2018. Reward-based crowdfunding of entrepreneurial projects: the effect of local altruism and localized social capital on proponents' success. Small Business Economics 50, 307-324.

Grinblatt, M., Keloharju, M., 2009. Sensation seeking, overconfidence, and trading activity. The Journal of Finance 64, 549-578.

Herzenstein, M., Dholakia, U. M., Andrews, R. L., 2011. Strategic herding behavior in peer-topeer loan auctions. Journal of Interactive Marketing 25, 27-36.

Hildebrand, T., Puri, M., Rocholl, J., 2016. Adverse incentives in crowdfunding. Management Science 63, 587-608.

Hoffmann, A. O., 2007. Individual investors' needs and the investment professional: Lessons from marketing. Journal of Investment Consulting 8, 80-91.

Hornuf, L., Schwienbacher, A., 2018. Market mechanisms and funding dynamics in equity crowdfunding. Journal of Corporate Finance 50, 556-574.

Horvath, P., Zuckerman, M., 1993. Sensation seeking, risk appraisal, and risky behavior. Personality and individual differences 14, 41-52.

Iyer, R., Khwaja, A. I., Luttmer, E. F., Shue, K., 2015. Screening peers softly: Inferring the quality of small borrowers. Management Science 62, 1554-1577.

Kawai, K., Onishi, K., Uetake, K., 2014. Signaling in online credit markets .

Keele, L., Kelly, N. J., 2006. Dynamic models for dynamic theories: The ins and outs of lagged dependent variables. Political analysis 14, 186-205.

Kumar, A., 2009. Who gambles in the stock market? The Journal of Finance 64, 1889-1933. 
Liao, C., 2017. Risk taking begets risk taking: Evidence from casino openings and investor portfolios.

Lin, M., Prabhala, N. R., Viswanathan, S., 2013. Judging borrowers by the company they keep: Friendship networks and information asymmetry in online peer-to-peer lending. Management Science 59, 17-35.

Lin, M., Viswanathan, S., 2015. Home bias in online investments: An empirical study of an online crowdfunding market. Management Science 62, 1393-1414.

Michels, J., 2012. Do unverifiable disclosures matter? evidence from peer-to-peer lending. The Accounting Review 87, 1385-1413.

Mollick, E. R., 2016. Containing multitudes: the many impacts of kickstarter funding .

Moritz, A., Block, J. H., 2016. Crowdfunding: A literature review and research directions. In: Crowdfunding in Europe, Springer, pp. 25-53.

Newey, W. K., West, K. D., 1987. Hypothesis testing with efficient method of moments estimation. International Economic Review pp. 777-787.

Nosek, B. A., Hawkins, C. B., Frazier, R. S., 2011. Implicit social cognition: From measures to mechanisms. Trends in cognitive sciences 15, 152-159.

Oster, E., 2004. Are all lotteries regressive? evidence from the powerball. National Tax Journal pp. $179-187$.

Parhankangas, A., Renko, M., 2017. Linguistic style and crowdfunding success among social and commercial entrepreneurs. Journal of Business Venturing 32, 215-236.

Pierrakis, Y., Collins, L., 2013. Banking on each other: Peer-to-peer lending to business: evidence from funding circle .

Pope, D. G., Sydnor, J. R., 2011. What's in a picture? evidence of discrimination from prosper. com. Journal of Human resources 46, 53-92.

Ramcharan, R., Crowe, C., 2013. The impact of house prices on consumer credit: evidence from an internet bank. Journal of Money, Credit and Banking 45, 1085-1115.

Ravina, E., 2012. Love \& loans: The effect of beauty and personal characteristics in credit markets .

Raylu, N., Oei, T. P., 2002. Pathological gambling: A comprehensive review. Clinical psychology review 22, 1009-1061.

Ryan, R. M., Deci, E. L., 2000. Intrinsic and extrinsic motivations: Classic definitions and new directions. Contemporary educational psychology 25, 54-67.

Ryu, S., Kim, Y.-G., 2016. A typology of crowdfunding sponsors: Birds of a feather flock together? Electronic Commerce Research and Applications 16, 43-54.

Sauermann, H., Franzoni, C., Shafi, K., 2019. Crowdfunding scientific research: Descriptive insights and correlates of funding success. PloS one 14, e0208384.

Signori, A., Vismara, S., 2018. Does success bring success? the post-offering lives of equitycrowdfunded firms. Journal of Corporate Finance 50, 575-591.

Wei, Z., Lin, M., 2016. Market mechanisms in online peer-to-peer lending. Management Science $63,4236-4257$. 
Wilkins, A. S., 2018. To lag or not to lag?: re-evaluating the use of lagged dependent variables in regression analysis. Political Science Research and Methods 6, 393-411.

Wooldridge, J. M., 2015. Introductory econometrics: A modern approach. Nelson Education.

Zhang, J., Liu, P., 2012. Rational herding in microloan markets. Management science 58, 892912.

Zuckerman, M., 1994. Behavioral expressions and biosocial bases of sensation seeking. Cambridge university press. 
Table 1: Descriptive Statistics

This table presents summary statistics for variables used in this study. See Table A4 for the definition of these variables.

\begin{tabular}{|c|c|c|c|c|c|c|}
\hline & Count & Mean & Median & $\begin{array}{l}\text { Standard de- } \\
\text { viation }\end{array}$ & Min & $\operatorname{Max}$ \\
\hline \multicolumn{7}{|l|}{ Crowdfunding Data Characteristics } \\
\hline Bid size (Individual lenders) & $6,485,228$ & 75.15 & 50.00 & 152.53 & 25.00 & 25000.00 \\
\hline Bid size (Institutional lenders) & 39,312 & 167.73 & 57.00 & 408.72 & 25.00 & 15000.00 \\
\hline Listing size & 314,408 & 7785.90 & 5000.00 & 6394.19 & 1000.00 & 25000.00 \\
\hline Loan size & 30,685 & 6065.08 & 4500.00 & 5423.66 & 1000.00 & 25000.00 \\
\hline Interest rate on loans & 30,685 & 0.19 & 0.17 & 0.08 & 0.00 & 0.35 \\
\hline \multicolumn{7}{|l|}{ Aggregate US Sample Variables } \\
\hline Powerball (mn USD) & 1,189 & 69.96 & 52.00 & 57.04 & 15.00 & 300.00 \\
\hline Mega Millions (mn USD) & 1,189 & 67.39 & 48.00 & 60.57 & 12.00 & 390.00 \\
\hline Powerball + Mega Millions (mn USD) & 1,189 & 137.35 & 119.00 & 86.39 & 27.00 & 550.00 \\
\hline Log (Powerball) & 1,189 & 3.94 & 3.95 & 0.79 & 2.71 & 5.70 \\
\hline Log (Mega Millions) & 1,189 & 3.84 & 3.87 & 0.88 & 2.48 & 5.97 \\
\hline Log (Powerball+Mega Millions) & 1,189 & 4.73 & 4.78 & 0.63 & 3.30 & 6.31 \\
\hline Log (Bid amount) & 1,189 & 12.59 & 12.84 & 0.96 & 3.93 & 14.04 \\
\hline Log (Bid number) & 1,189 & 8.42 & 8.56 & 0.73 & 1.10 & 9.65 \\
\hline Log (Total listing) & 1,189 & 16.09 & 16.60 & 0.94 & 12.12 & 17.50 \\
\hline Log (Bid amount of institutional investors) & 1,189 & 7.49 & 8.00 & 2.11 & 0.00 & 12.29 \\
\hline Share of institutional investor bids & 1,189 & 0.01 & 0.01 & 0.03 & 0.00 & 0.43 \\
\hline Share of winning bids & 1,189 & 0.67 & 0.65 & 0.10 & 0.47 & 1.00 \\
\hline Weighted average lender rate & 1,189 & 0.21 & 0.23 & 0.03 & 0.15 & 0.32 \\
\hline S\&P 500 return & 1,189 & 0.00 & 0.00 & 0.01 & -0.09 & 0.12 \\
\hline \multicolumn{7}{|l|}{ Listing-day Level and Bid Level Reg. Variables } \\
\hline \multicolumn{7}{|l|}{ At Listing-day Level: } \\
\hline $\log$ (Bid amount) & $1,288,572$ & 2.41 & 0.00 & 2.91 & 0.00 & 13.30 \\
\hline Log (Bid number) & $1,288,572$ & 0.74 & 0.00 & 1.12 & 0.00 & 6.49 \\
\hline Log (Powerball) & $1,288,572$ & 3.93 & 3.95 & 0.81 & 2.71 & 5.70 \\
\hline Log (Mega Millions) & $1,288,572$ & 3.83 & 3.87 & 0.87 & 2.48 & 5.97 \\
\hline Log (Powerball+Mega Millions) & $1,288,572$ & 4.72 & 4.78 & 0.63 & 3.30 & 6.31 \\
\hline Powerball + Mega Millions (mn USD) & $1,288,572$ & 136.24 & 119.00 & 85.72 & 27.00 & 550.00 \\
\hline Borrower debt to income ratio & $1,288,572$ & 0.40 & 0.22 & 1.07 & 0.00 & 10.01 \\
\hline \multicolumn{7}{|l|}{ At Bid Level: } \\
\hline Log (Bid amount) & $7,208,092$ & 4.06 & 3.93 & 0.61 & 3.26 & 10.13 \\
\hline Log (Powerball+Mega Millions) & $7,208,092$ & 4.71 & 4.75 & 0.63 & 3.30 & 6.31 \\
\hline Log (Bidding experience) & $7,208,092$ & 5.19 & 5.23 & 1.70 & 0.69 & 10.38 \\
\hline Log (Listing size) & $7,208,092$ & 9.03 & 9.10 & 0.79 & 6.91 & 10.13 \\
\hline Borrower debt to income ratio & $7,208,092$ & 0.31 & 0.20 & 0.84 & 0.00 & 10.01 \\
\hline \multicolumn{7}{|l|}{ California Sample Variables } \\
\hline California jackpot (mn USD) & 1,189 & 21.64 & 16.00 & 15.92 & 7.00 & 93.00 \\
\hline Log (California jackpot) & 1,189 & 2.85 & 2.77 & 0.65 & 1.95 & 4.53 \\
\hline Share of California bids & 1,189 & 0.26 & 0.23 & 0.07 & 0.00 & 0.65 \\
\hline Share of California bid count & 1,189 & 0.24 & 0.22 & 0.06 & 0.00 & 0.47 \\
\hline Normalized California bids & 1,189 & 0.27 & 0.24 & 0.16 & 0.00 & 1.50 \\
\hline Normalized California bid count & 1,189 & 0.25 & 0.23 & 0.14 & 0.00 & 1.13 \\
\hline Normalized non-California bids & 1,189 & 0.76 & 0.79 & 0.32 & 0.00 & 3.73 \\
\hline Normalized non-California bid count & 1,189 & 0.77 & 0.81 & 0.32 & 0.00 & 2.69 \\
\hline Share of institutional investor bids & 1,149 & 0.28 & 0.10 & 0.34 & 0.00 & 1.00 \\
\hline
\end{tabular}


Descriptive statistics continued.

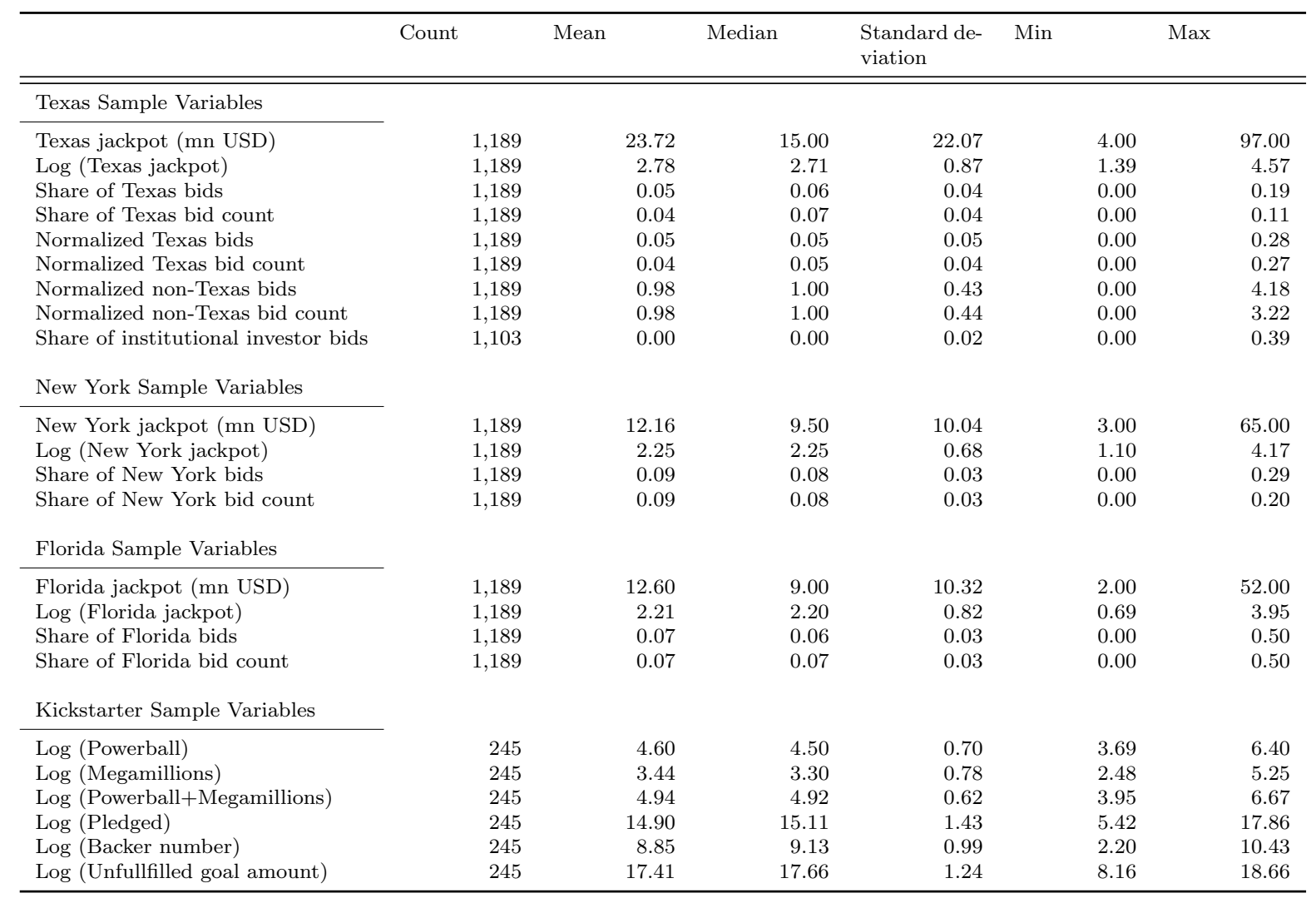




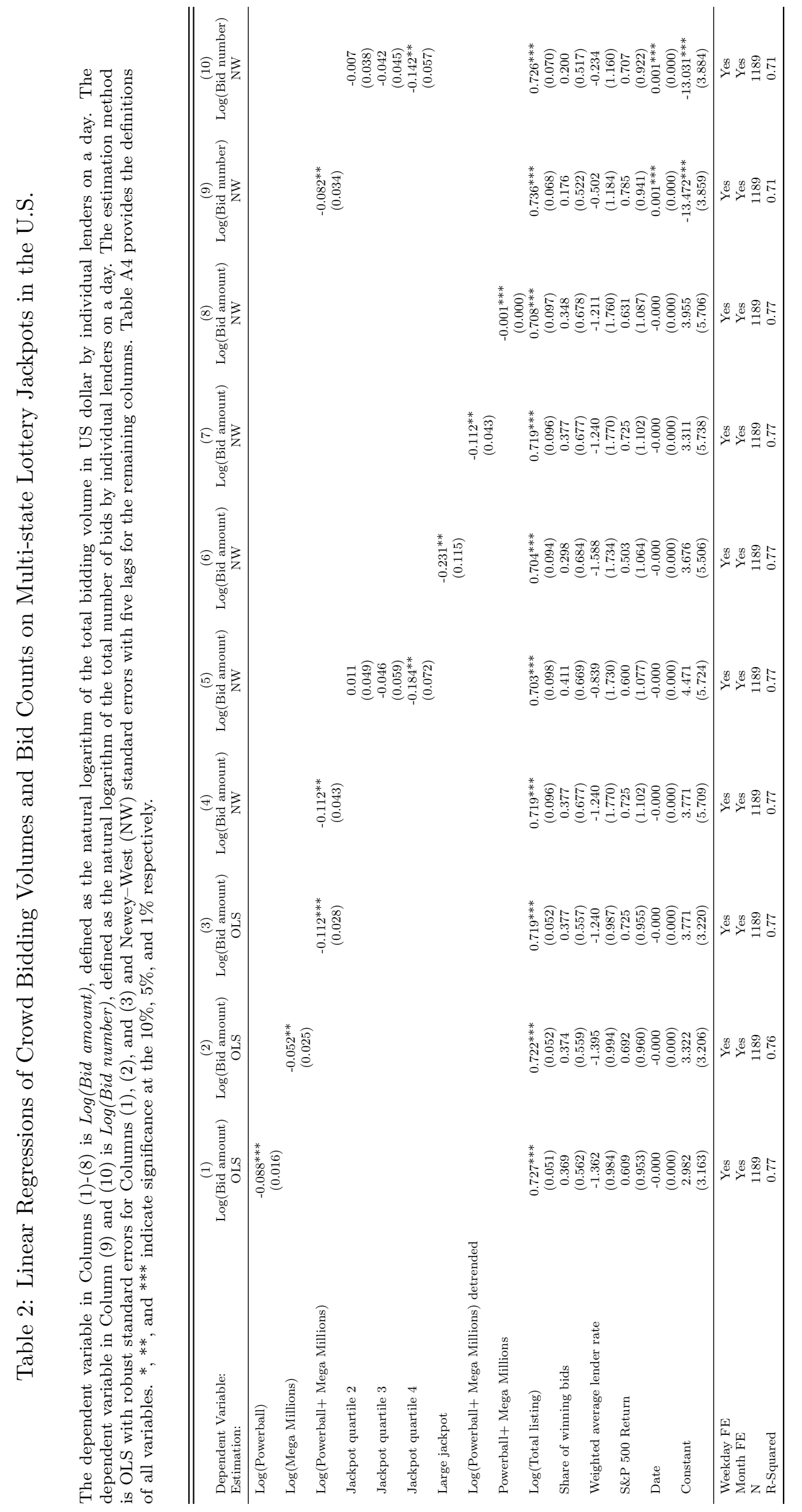




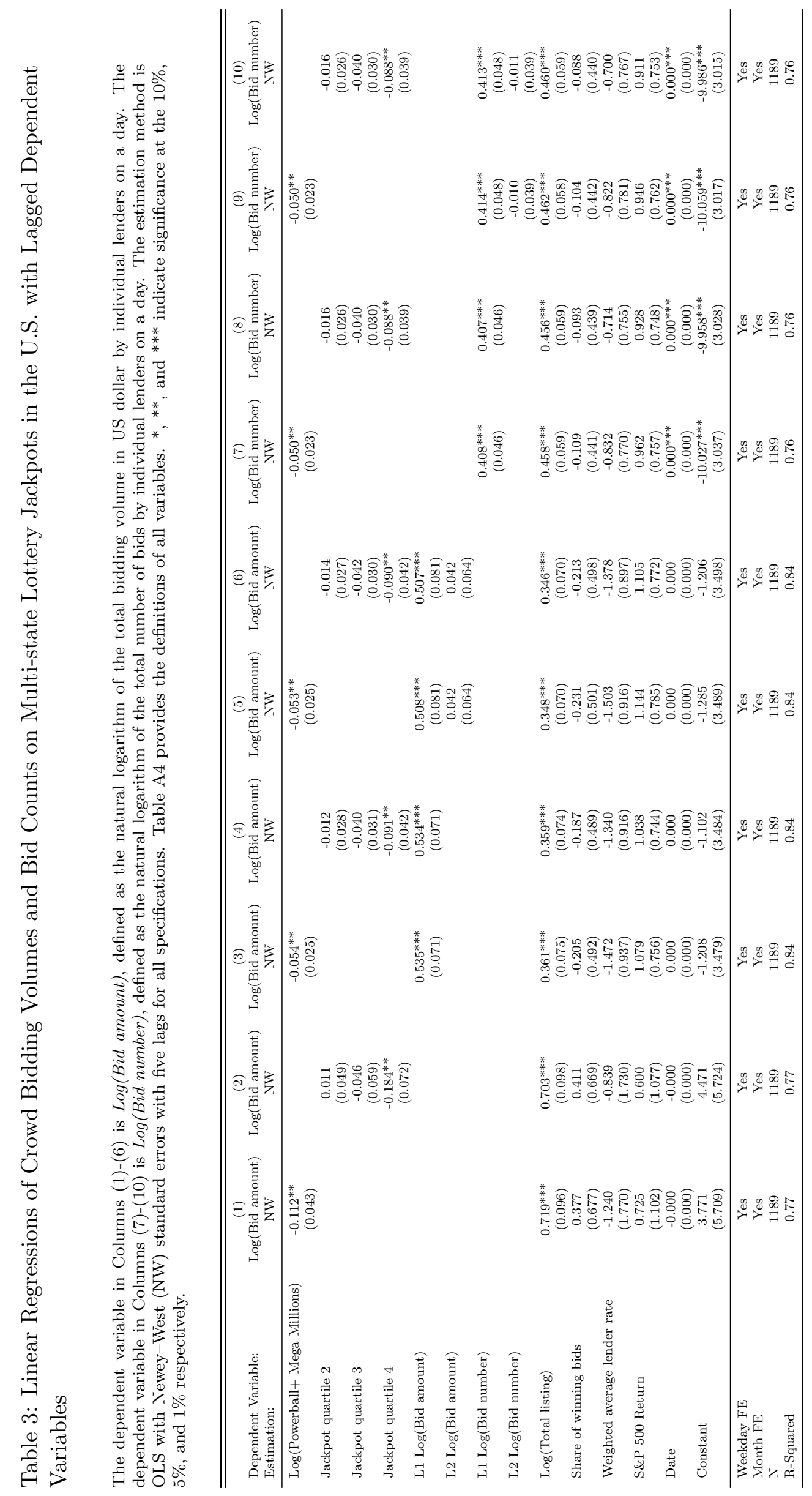




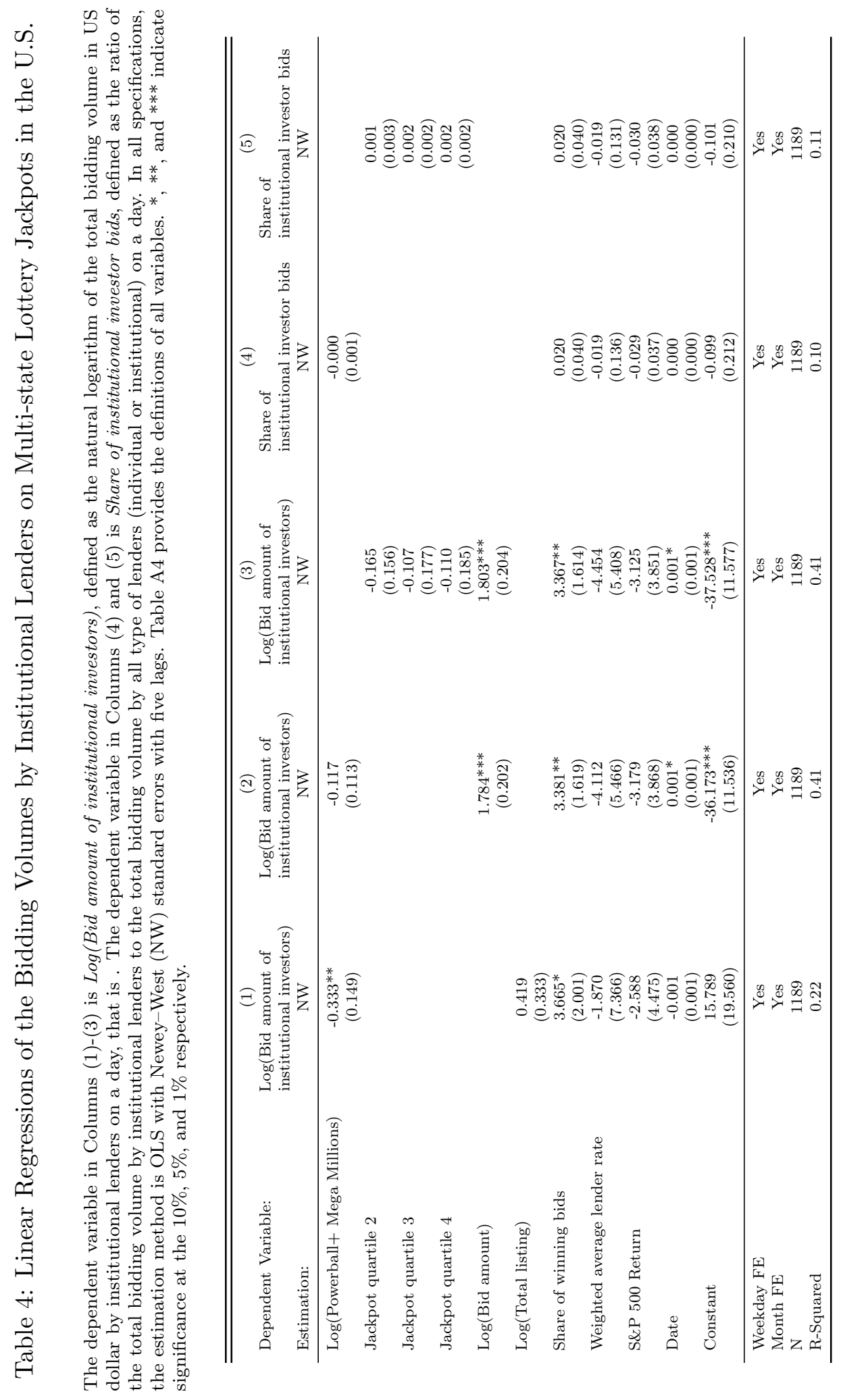




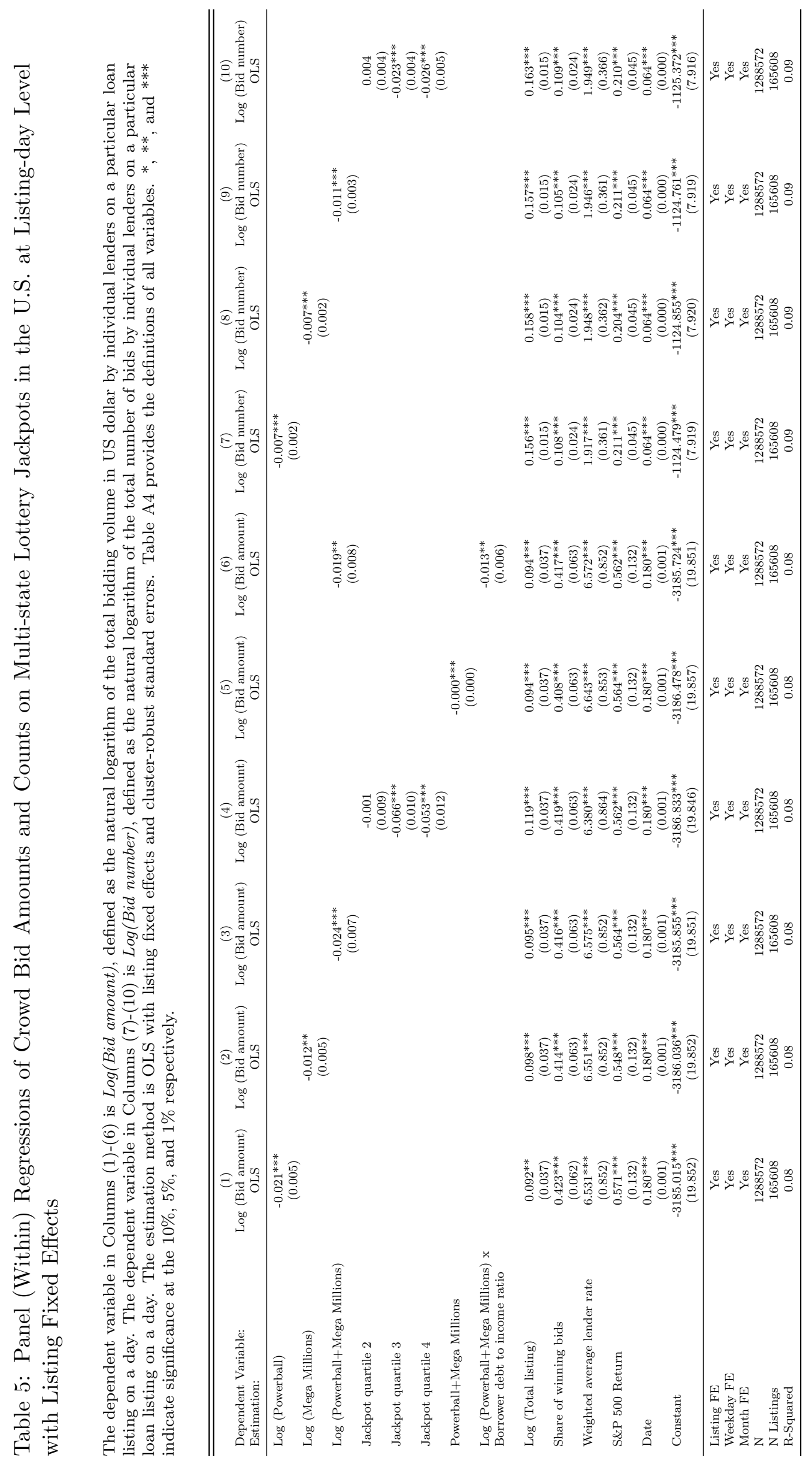




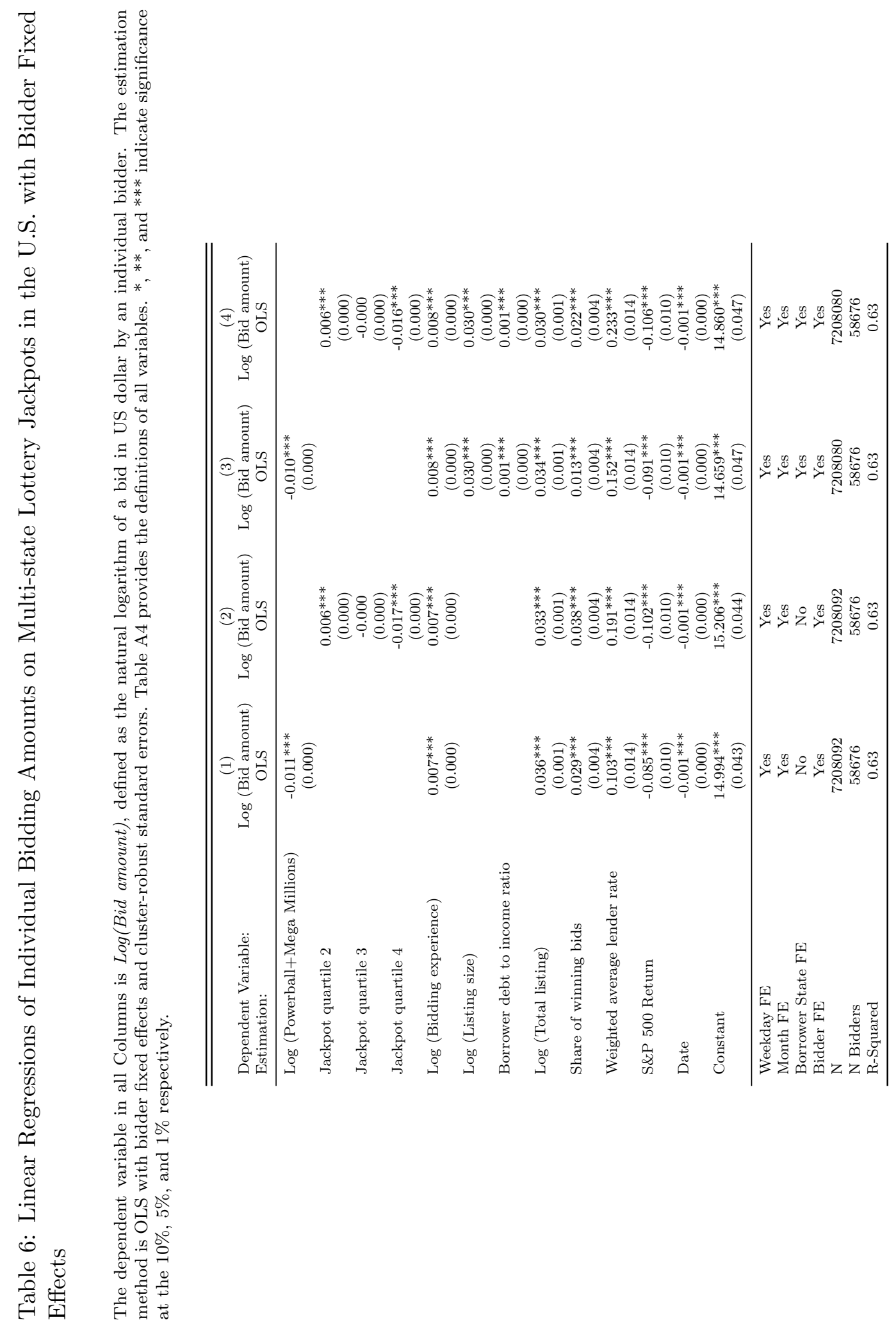




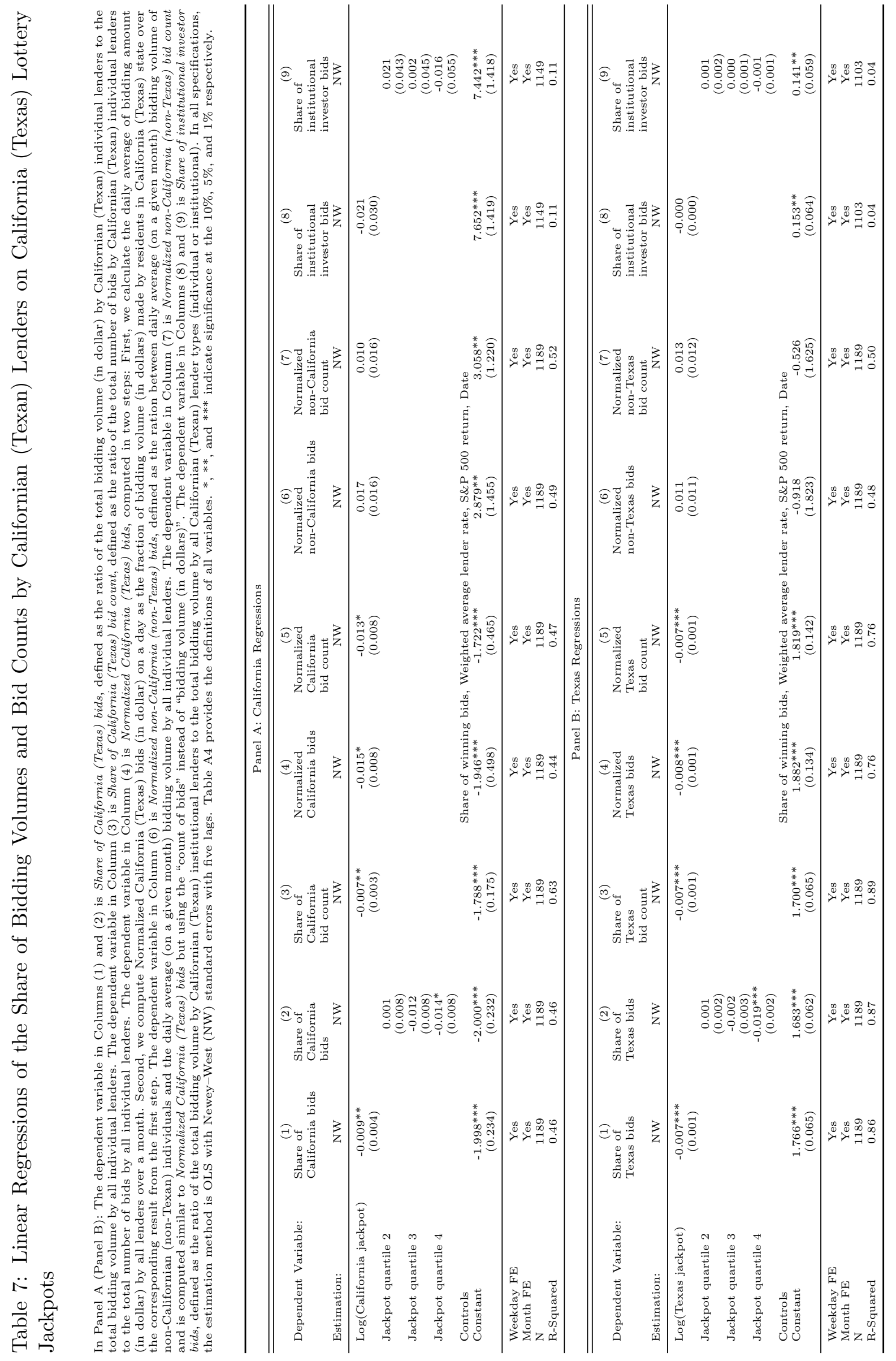




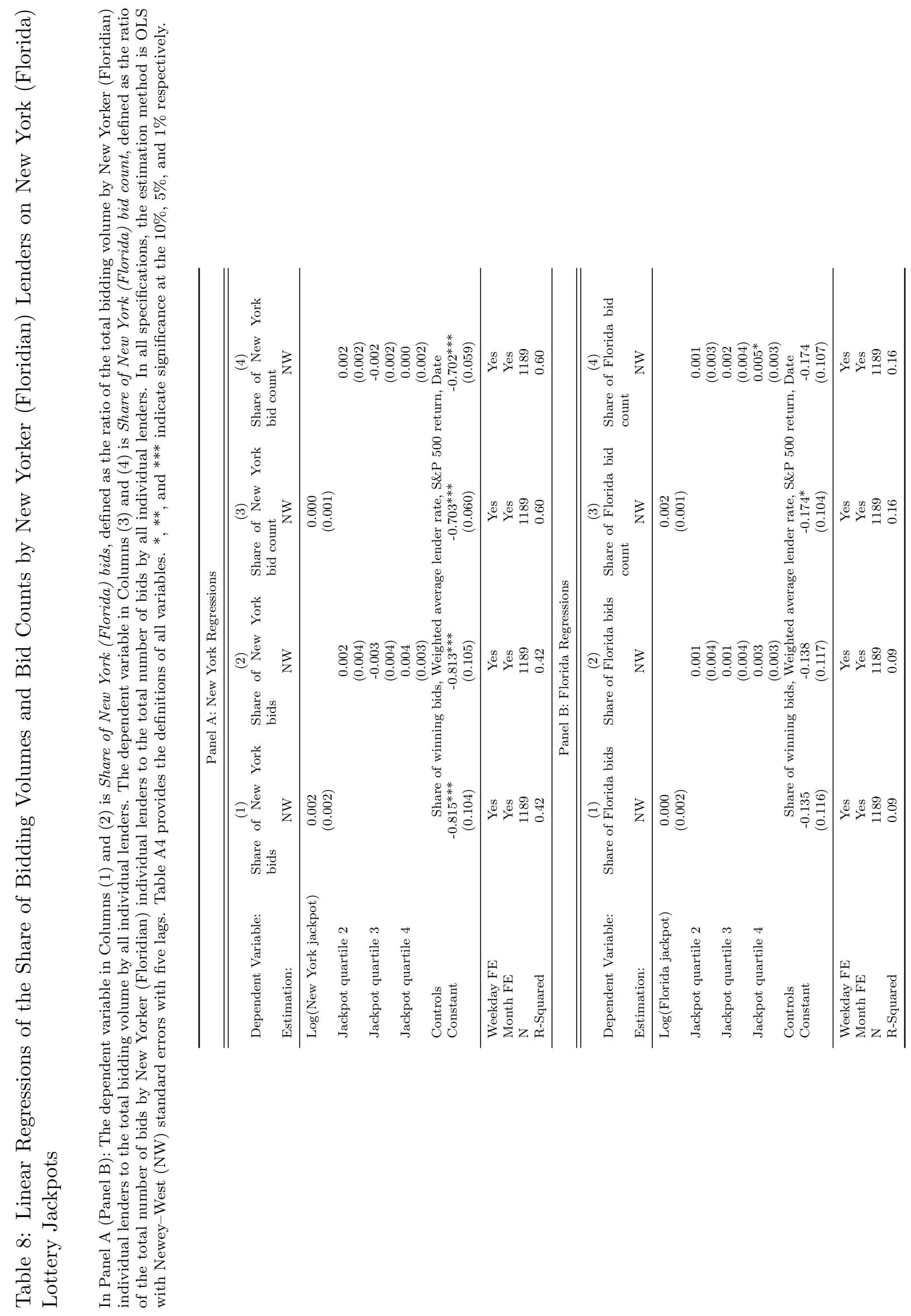




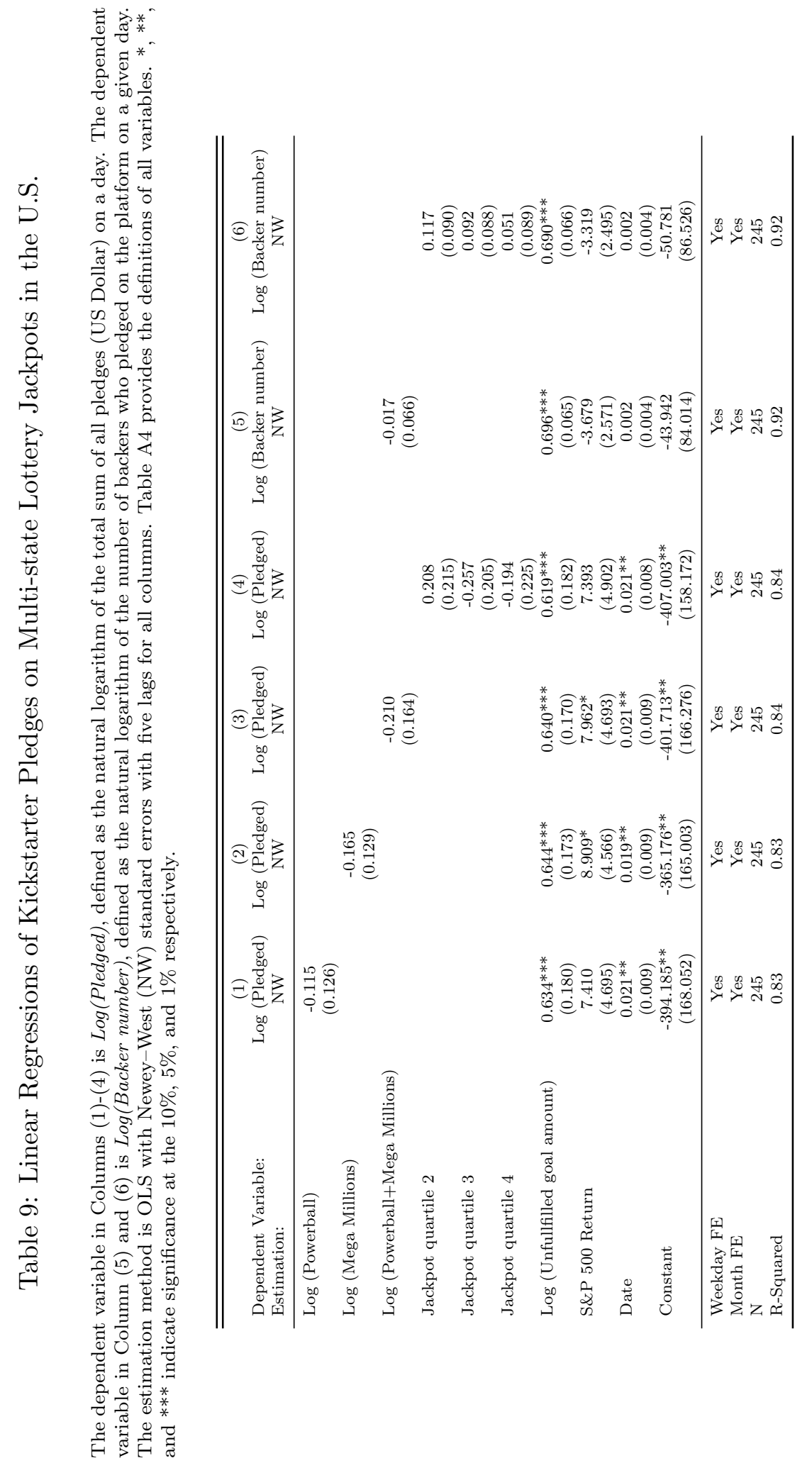




\section{Table A1: Evolution of Prosper Platform}

This table, modified from Freedman and Jin (2017), shows the timeline of policy changes in Prosper Marketplace.

\begin{tabular}{|c|c|}
\hline Date & Policy \\
\hline \multirow{3}{*}{ November 9,2005} & Open for business. \\
\hline & Min bid $\$ 50 ;$ Max bid $\$ 25,000$. \\
\hline & Credit info limited to credit grade \& debt-to-(self-reported)-income. \\
\hline April 19, 2006 & Introduce home ownership and verified bank account information for listings. \\
\hline May 30, 2006 & Reveal more credit info, home ownership status, and bank account status. \\
\hline October 19,2006 & Start group rating based on past loan performance. \\
\hline \multirow{5}{*}{ February 12,2007} & Disallow borrowers with score 520 or without score (NC). \\
\hline & Credit Grade E from 540-599 to 560-599. \\
\hline & Credit Grade HR from 540- to 520-559. \\
\hline & Reveal more credit info (e.g. amount delinquent). \\
\hline & $\begin{array}{l}\text { Allow friend endorsements; introducing friend funding }(\$ 25) \text { or borrowing }(\$ 50) \\
\text { rewards. }\end{array}$ \\
\hline August 17,2007 & Provide information on on-time vs. late payments. \\
\hline September 12,2007 & Eliminate group leader rewards ( $\$ 4 /$ new borrower; $\$ 12 /$ loan funding). \\
\hline \multirow[b]{2}{*}{ October 30,2007} & Add bidder guidance. \\
\hline & Introducing portfolio plans, allowing automatic bidding based on criteria. \\
\hline February 23,2008 & Allow search by friend bids and endorsements. \\
\hline April 15, 2008 & Raise interest rate cap to $36 \%$ except for TX (10\%) and SD (N/A). \\
\hline October 19,2008 & Prosper suspends new lending to register with SEC to create a secondary marketplace. \\
\hline \multirow{4}{*}{ April 28, 2009} & Prosper reopens (without full SEC approval). \\
\hline & Disallow borrowers with score below 640 . \\
\hline & $\begin{array}{l}\text { Opening secondary marketplace; i.e. a platform for lending institutions to put } \\
\text { any } \\
\text { loan with minimum } 3 \text { payments (auto, small business, etc) up for sale \& bidding. }\end{array}$ \\
\hline & $\begin{array}{l}\text { Credit Grade information is not systematically made available anymore, only spo- } \\
\text { radically; instead prosper scores are systematically shown for all listings (1-10). }\end{array}$ \\
\hline May 9,2009 & Prosper suspended again new lending/borrowing to complete SEC registration. \\
\hline July 13,2009 & Receives green-light from SEC. \\
\hline \multirow{3}{*}{ July 14,2009} & Prosper reopens. \\
\hline & $\begin{array}{l}\text { Implements a minimum bid rate (floor) on listings, calculated by adding national } \\
\text { average CD rate for loan term, to min estimated loss rate for each listing. }\end{array}$ \\
\hline & Minimum bid requirement at $\$ 25$. \\
\hline October 15,2010 & Loan terms expand from 36 months to 12 and 60 . Default is still at 36 . \\
\hline \multirow{4}{*}{ October 15,2010} & $\begin{array}{l}\text { Interest rates no more determined by Dutch-Auction, but by Prosper's formula } \\
\text { evaluating borrowers' credit risk. }\end{array}$ \\
\hline & Listings pulled from site as soon as fully funded. \\
\hline & No longer list HR (no credit history or w/ history of defaults) listings. \\
\hline & Credit grades are no longer listed. \\
\hline
\end{tabular}


Table A2: Availability of Prosper to Lenders from Various States

Table shows the timeline of admission and readmission of lenders from various states.

\begin{tabular}{|l|l|}
\hline \multicolumn{1}{|c|}{ Dates } & \multicolumn{1}{|c|}{ Prosper Opened to Lenders } \\
\hline Nov 9, 2005 - Feb 5, 2006 & Only available privately to investors in California and New Jersey \\
Feb 5, 2006 - Oct 19, 2008 & Open to lenders in All 50 US States \& D.C. \\
Apr 28, 2009 - May 9, 2009 & Only open in California temporarily \\
Jul 14, 2009 & Opens lending in 14 states: CA, CO, DE, GA, IL, MN, MT, NV, NY, SC, SD, UT, WI, WY \\
Jul 15, 2009 & Florida \\
Jul 20, 2009 & Hawaii, Washington \\
Jul 31, 2009 & Maine \\
Aug 6, 2009 & Conneticut, Idaho, New Hampshire, Oregan \\
Aug 14, 2009 & Louisiana and Missouri \\
Aug 19, 2009 & Rhode Island and Virginia \\
Jan 21, 2010 & Mississippi \\
May 5, 2010 & Alaska \\
Jun 28, 2010 & DC \\
\hline
\end{tabular}




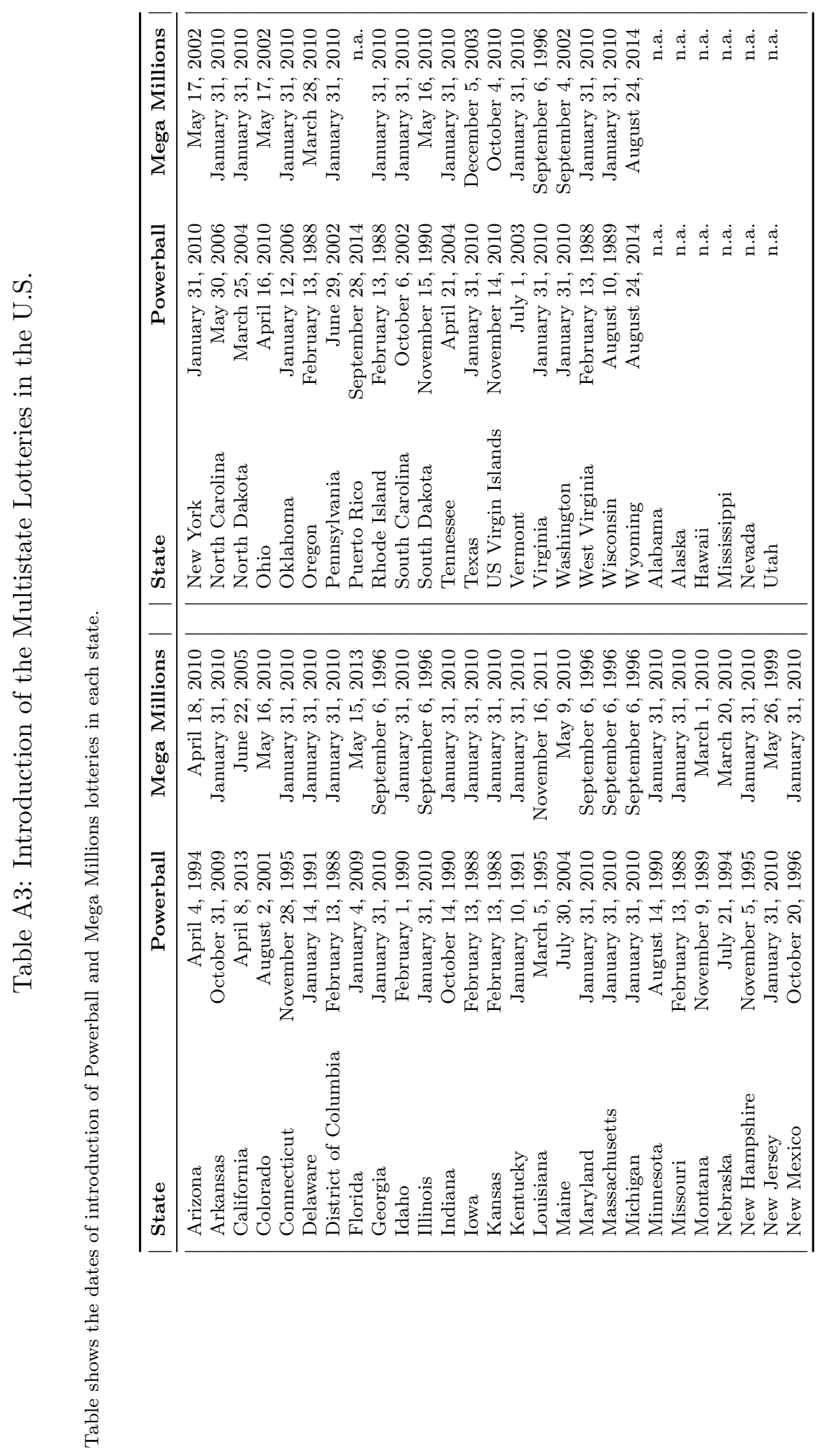




\section{Table A4: Variable Definitions}

This table lists the definitions of all variables used.

\begin{tabular}{|c|c|}
\hline Variable & Definition \\
\hline \multicolumn{2}{|l|}{ Crowdfunding Data } \\
\hline Bid size (Individual lenders) & Dollar value of a bid made by an individual lender. \\
\hline Bid size (Institutional lenders) & Dollar value of a bid made by an institutional lender. \\
\hline Listing size & Dollar value of a loan listing. \\
\hline Loan size & Dollar value of a loan. This is the amount of funding the borrower requests and successfully recieves. \\
\hline Interest rate on loans & Fixed interest rate on a loan. \\
\hline Borrower debt to income ratio & Borrower's debt to income ratio. \\
\hline Log (Bidding experience) & Natural logarithm of the total number of bids by an individual lender prior to its current bid. \\
\hline \multicolumn{2}{|l|}{ Aggregate US Sample Variables } \\
\hline Powerball (mn USD) & Dollar value of the Powerball jackpot on a day. \\
\hline Megamillions (mn USD) & Dollar value of the Mega Millions jackpot on a day. \\
\hline Powerball + Megamillions (mn USD) & $\begin{array}{l}\text { Dollar value of the combined Powerball and Mega Millions jackpots on a day. There are four weekly } \\
\text { drawings - Wednesdays and Saturdays for Powerball, and Tuesdays and Fridays for Mega Millions. }\end{array}$ \\
\hline Log (Powerball) & Natural logarithm of Powerball jackpot. \\
\hline Log (Megamillions) & Natural logarithm of Mega Millions jackpot. \\
\hline Log (Powerball+Megamillions) & Natural logarithm of the combined Powerball and Mega Millions jackpots. \\
\hline Large jackpot & Equals to 1 if combined Powerball and Mega Millions jackpots is in the top $10 \%$ percentile. \\
\hline Log (Bid amount) & Natural logarithm of the total bidding volume by individual lenders on a day. \\
\hline Log (Bid number) & Natural logarithm of the total number of bids by individual lenders on a day. \\
\hline Log (Total listing) & Natural logarithm of the total listing size open to bidding on a day. \\
\hline $\begin{array}{l}\text { Log (Bid amount of institutional in- } \\
\text { vestors) }\end{array}$ & Natural logarithm of the total bidding volume by institutional lenders on a day. \\
\hline Share of institutional investor bids & $\begin{array}{l}\text { Ratio of the total bidding volume by institutional lenders to the total bidding volume by all types of } \\
\text { lenders (individual or institutional). }\end{array}$ \\
\hline Share of winning bids & $\begin{array}{l}\text { The status of a bid is one of the following: Winning, partially participating, outbid, bid withdrawn. } \\
\text { For a given day, share of winning bids is equal to the percentage of winning bids among all bids made } \\
\text { on that day. }\end{array}$ \\
\hline Weighted average lender rate & $\begin{array}{l}\text { For a given day } t \text {, lender rate is the rate that lenders would receive on the listing if the loan were to } \\
\text { close on day } t \text {. To be able to compute weighted average lender rate on day } t \text {, we need to compute the } \\
\text { weight of each listing among all listings available on day } t \text {. For a given day } t \text {, the weight of a listing } L \\
\text { is equal to the ratio of the size of } L \text { to the size of all listings open to bidding on } t \text {. After we compute } \\
\text { the weight of each listing open to bidding on day t, we multiply the lender rate of each listing with the } \\
\text { weight of each listing. Then we sum the values of all weighted lender rates together to compute the } \\
\text { weighted average lender date on a day. }\end{array}$ \\
\hline S\&P 500 Return & $\begin{array}{l}\text { Value weighted return on the S\&P } 500 \text { index on day t. Values of the index return on Saturday and } \\
\text { Sunday are assumed as equal to the return on the last Friday. }\end{array}$ \\
\hline Date & Date is the linear time trend. \\
\hline \multicolumn{2}{|l|}{ California Sample Variables } \\
\hline California jackpot (mn USD) & Dollar value of the California lottery jackpot on a day. \\
\hline Log (California jackpot) & Natural logarithm of California lottery jackpot. \\
\hline Share of California bids & $\begin{array}{l}\text { Ratio of the total bidding volume by Californian individual lenders to the total bidding volume by all } \\
\text { individual lenders. }\end{array}$ \\
\hline Share of California bid count & $\begin{array}{l}\text { Ratio of the total number of bids by Californian individual lenders to the total number of bids by all } \\
\text { individual lenders. }\end{array}$ \\
\hline
\end{tabular}


Table A4 continued.

\begin{tabular}{|c|c|}
\hline Normalized California bids & $\begin{array}{l}\text { We first calculate the total bidding volume by all individual lenders in month } \mathrm{m} \text {, then we divide this } \\
\text { total by the number of days in month } \mathrm{m} \text {. This way we find the average daily bidding volume by all } \\
\text { individual lenders on Prosper in month } \mathrm{m} \text {. Then for a given day } \mathrm{t} \text { in month } \mathrm{m} \text {, normalized California } \\
\text { bids is equal to bidding volume of Californian individuals on day } \mathrm{t} \text { divided by the average daily bidding } \\
\text { volume by all individual lenders on Prosper in month } \mathrm{m} \text {. }\end{array}$ \\
\hline Normalized California bid count & $\begin{array}{l}\text { We first calculate the total number of bids by all individual lenders in month } \mathrm{m} \text {, then we divide this } \\
\text { total by the number of days in month } \mathrm{m} \text {. This way we find the average daily bid count by all individual } \\
\text { lenders on Prosper in month } \mathrm{m} \text {. Then for a given day } \mathrm{t} \text { in month } \mathrm{m} \text {, normalized California bid count } \\
\text { is equal to the number of bids by Californian individuals on day } \mathrm{t} \text { divided by the average daily number } \\
\text { of bids by all individual lenders on Prosper in month } \mathrm{m} \text {. }\end{array}$ \\
\hline Normalized non-California bids & $\begin{array}{l}\text { We first calculate the total bidding volume by all individual lenders in month } \mathrm{m} \text {, then we divide } \\
\text { this total by the number of days in month } \mathrm{m} \text {. This way we find the average daily bidding volume } \\
\text { by all individual lenders on Prosper in month } \mathrm{m} \text {. Then for a given day } \mathrm{t} \text { in month } \mathrm{m} \text {, normalized } \\
\text { non-California bids is equal to bidding volume of non-Californian individuals on day } \mathrm{t} \text { divided by the } \\
\text { average daily bidding volume by all individual lenders on Prosper in month } \mathrm{m} \text {. }\end{array}$ \\
\hline Normalized non-California bid count & $\begin{array}{l}\text { We first calculate the total number of bids by all individual lenders in month } \mathrm{m} \text {, then we divide this } \\
\text { total by the number of days in month } \mathrm{m} \text {. This way we find the average daily bid count by all individual } \\
\text { lenders on Prosper in month } \mathrm{m} \text {. Then for a given day } \mathrm{t} \text { in month } \mathrm{m} \text {, normalized non-California bid } \\
\text { count is equal to the number of bids by non-Californian individuals on day } \mathrm{t} \text { divided by the average } \\
\text { daily number of bids by all individual lenders on Prosper in month } \mathrm{m} \text {. }\end{array}$ \\
\hline Share of institutional investor bids & $\begin{array}{l}\text { Ratio of the total bidding volume by Californian institutional lenders to the total bidding volume by } \\
\text { all Californian lender types (individual or institutional). }\end{array}$ \\
\hline \multicolumn{2}{|l|}{ Texas Sample Variables } \\
\hline Texas jackpot (mn USD) & Dollar value of the Texas lottery jackpot on a day. \\
\hline Log (Texas jackpot) & Natural logarithm of Texas lottery jackpot. \\
\hline Share of Texas bids & $\begin{array}{l}\text { Ratio of the total bidding volume by Texan individual lenders to the total bidding volume by all } \\
\text { individual lenders. }\end{array}$ \\
\hline Share of Texas bid count & $\begin{array}{l}\text { Ratio of the total number of bids by Texan individual lenders to the total number of bids by all } \\
\text { individual lenders. }\end{array}$ \\
\hline Normalized Texas bids & $\begin{array}{l}\text { We first calculate the total bidding volume by all individual lenders in month } \mathrm{m} \text {, then we divide this } \\
\text { total by the number of days in month } \mathrm{m} \text {. This way we find the average daily bidding volume by all } \\
\text { individual lenders on Prosper in month } \mathrm{m} \text {. Then for a given day } \mathrm{t} \text { in month } \mathrm{m} \text {, normalized Texas bids } \\
\text { is equal to bidding volume of Texan individuals on day } \mathrm{t} \text { divided by the average daily bidding volume } \\
\text { by all individual lenders on Prosper in month } \mathrm{m} \text {. }\end{array}$ \\
\hline Normalized Texas bid count & $\begin{array}{l}\text { We first calculate the total number of bids by all individual lenders in month } \mathrm{m} \text {, then we divide this } \\
\text { total by the number of days in month } \mathrm{m} \text {. This way we find the average daily bid count by all individual } \\
\text { lenders on Prosper in month } \mathrm{m} \text {. Then for a given day } \mathrm{t} \text { in month } \mathrm{m} \text {, normalized Texan bid count is } \\
\text { equal to the number of bids by Texan individuals on day } \mathrm{t} \text { divided by the average daily number of bids } \\
\text { by all individual lenders on Prosper in month } \mathrm{m} \text {. }\end{array}$ \\
\hline Normalized non-Texas bids & $\begin{array}{l}\text { We first calculate the total bidding volume by all individual lenders in month } \mathrm{m} \text {, then we divide this } \\
\text { total by the number of days in month } \mathrm{m} \text {. This way we find the average daily bidding volume by all } \\
\text { individual lenders on Prosper in month } \mathrm{m} \text {. Then for a given day } \mathrm{t} \text { in month } \mathrm{m} \text {, normalized non-Texas } \\
\text { bids is equal to bidding volume of non-Texan individuals on day } \mathrm{t} \text { divided by the average daily bidding } \\
\text { volume by all individual lenders on Prosper in month } \mathrm{m} \text {. }\end{array}$ \\
\hline Normalized non-Texas bid count & $\begin{array}{l}\text { We first calculate the total number of bids by all individual lenders in month } \mathrm{m} \text {, then we divide this } \\
\text { total by the number of days in month } \mathrm{m} \text {. This way we find the average daily bid count by all individual } \\
\text { lenders on Prosper in month } \mathrm{m} \text {. Then for a given day } \mathrm{t} \text { in month } \mathrm{m} \text {, normalized non-Texas bid count } \\
\text { is equal to the number of bids by non-Texan individuals on day } \mathrm{t} \text { divided by the average daily number } \\
\text { of bids by all individual lenders on Prosper in month } \mathrm{m} \text {. }\end{array}$ \\
\hline Share of institutional investor bids & $\begin{array}{l}\text { Ratio of the total bidding volume by Texan institutional lenders to the total bidding volume by all } \\
\text { Texan lender types (individual or institutional). }\end{array}$ \\
\hline
\end{tabular}


Table A4 continued.

\begin{tabular}{|c|c|}
\hline Variable & Definition \\
\hline \multicolumn{2}{|l|}{ New York Sample Variables } \\
\hline New York jackpot (mn USD) & Dollar value of the New York lottery jackpot on a day. \\
\hline Log (New York jackpot) & Natural logarithm of New York lottery jackpot. \\
\hline Share of New York bids & $\begin{array}{l}\text { Ratio of the total bidding volume by New Yorker individual lenders to the total bidding volume by } \\
\text { all individual lenders. }\end{array}$ \\
\hline Share of New York bid count & $\begin{array}{l}\text { Ratio of the total number of bids by New Yorker individual lenders to the total number of bids by } \\
\text { all individual lenders. }\end{array}$ \\
\hline \multicolumn{2}{|l|}{ Florida Sample Variables } \\
\hline Florida jackpot (mn USD) & Dollar value of the Florida lottery jackpot on a day. \\
\hline Log (Florida jackpot) & Natural logarithm of Florida lottery jackpot. \\
\hline Share of Florida bids & $\begin{array}{l}\text { Ratio of the total bidding volume by Floridian individual lenders to the total bidding volume by all } \\
\text { individual lenders. }\end{array}$ \\
\hline Share of Florida bid count & $\begin{array}{l}\text { Ratio of the total number of bids by Floridian individual lenders to the total number of bids by all } \\
\text { individual lenders. }\end{array}$ \\
\hline \multicolumn{2}{|l|}{ Kickstarter Sample Variables } \\
\hline Log (Powerball) & Natural logarithm of Powerball jackpot. \\
\hline Log (Megamillions) & Natural logarithm of Mega Millions jackpot. \\
\hline Log (Powerball+Megamillions) & Natural logarithm of the combined Powerball and Mega Millions jackpots. \\
\hline Log (Pledged) & Natural logarithm of the dollar value of total daily pledges. \\
\hline Log (Backer number) & Natural logarithm of the number of backers who pledged on the platform on a given day. \\
\hline Log (Unfullfilled goal amount) & $\begin{array}{l}\text { Every project on Kickstarter has a funding target and a certain deadline to raise funds. For a given } \\
\text { day, we first compute the total unfulfilled goal amount for every active project, then by summing } \\
\text { these values we compute the total unfulfilled goal amount on the platform. Then, we take the } \\
\text { natural logarithm of the unfullfilled goal amount. }\end{array}$ \\
\hline
\end{tabular}




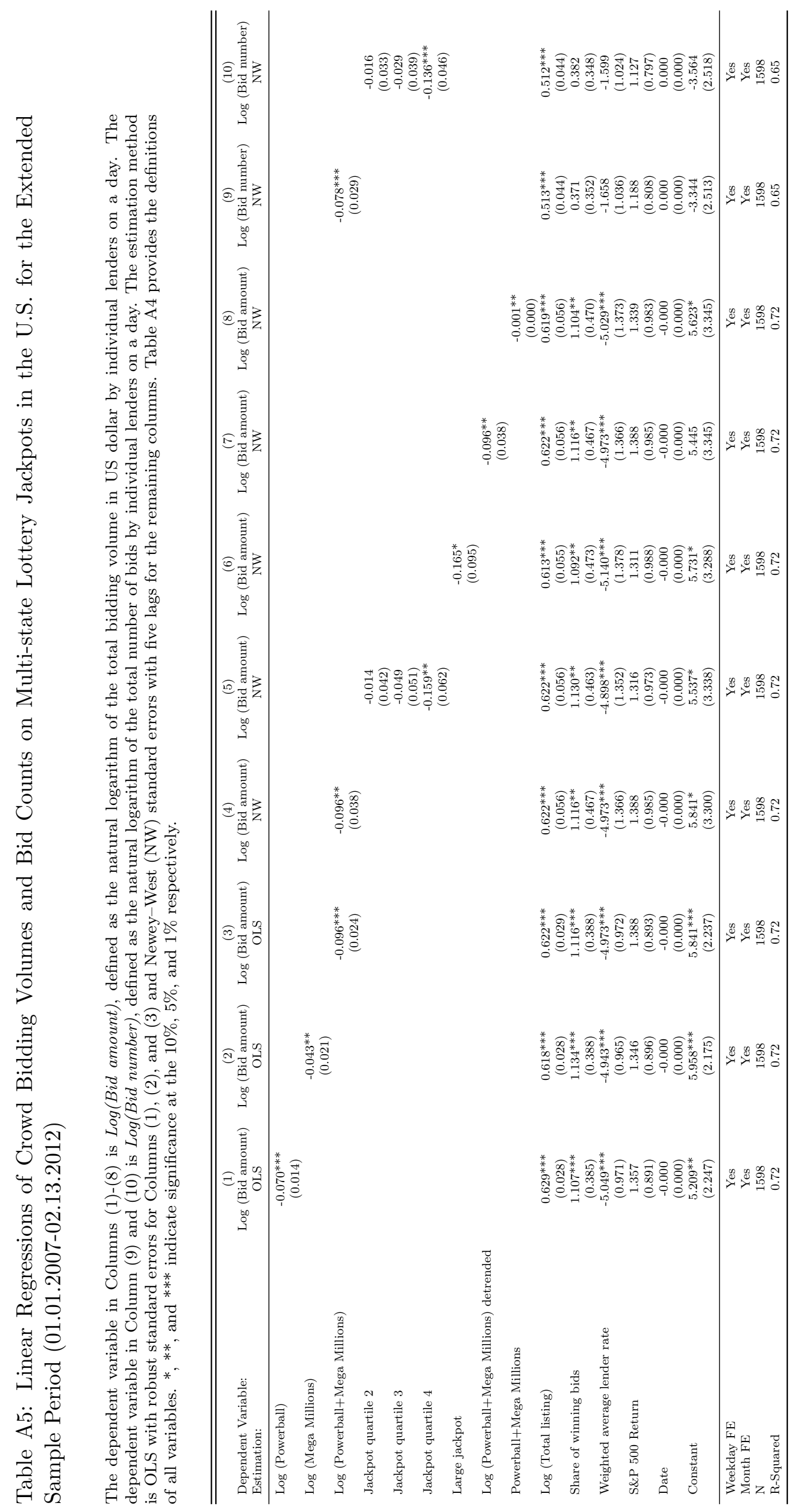




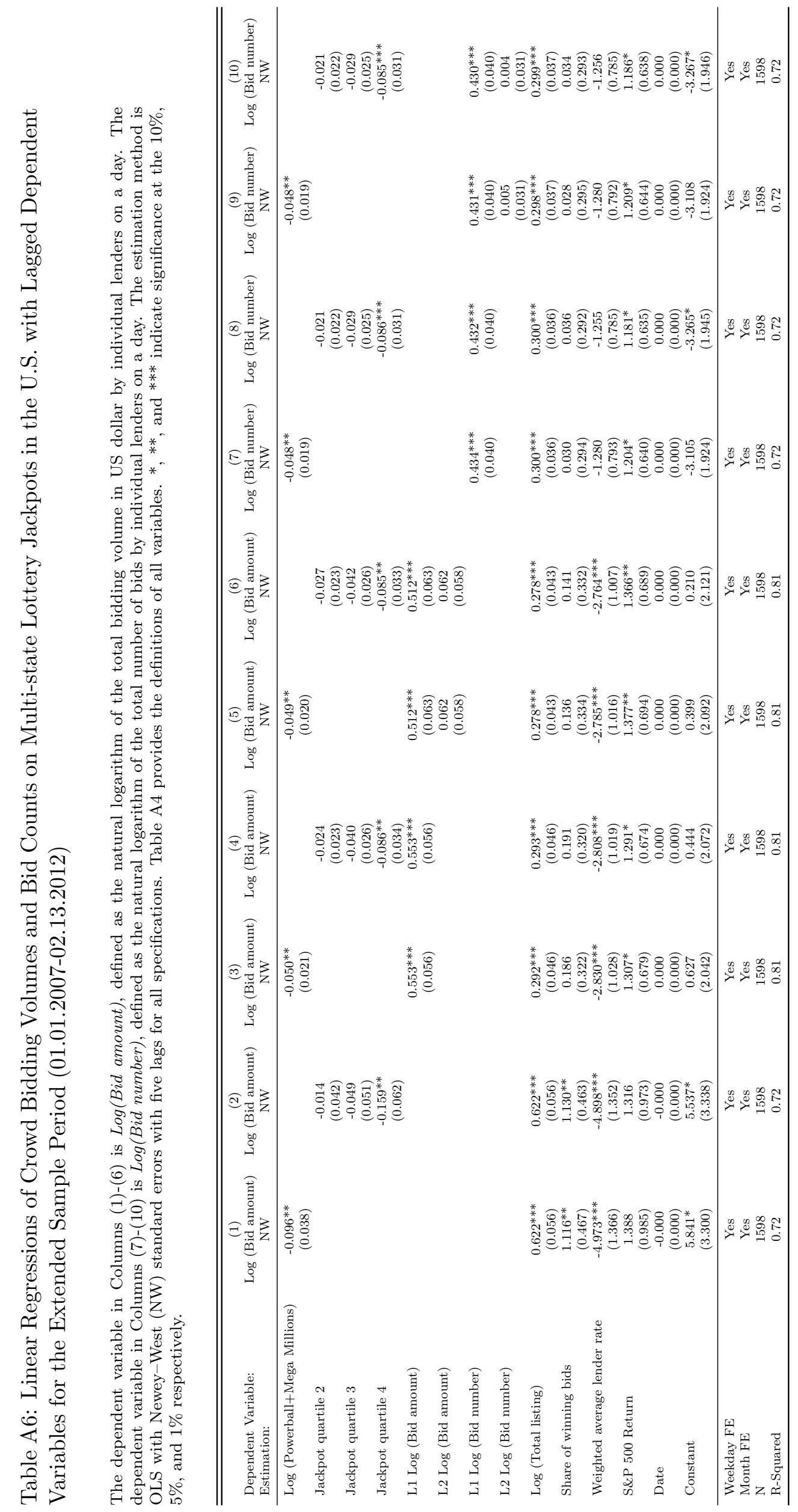




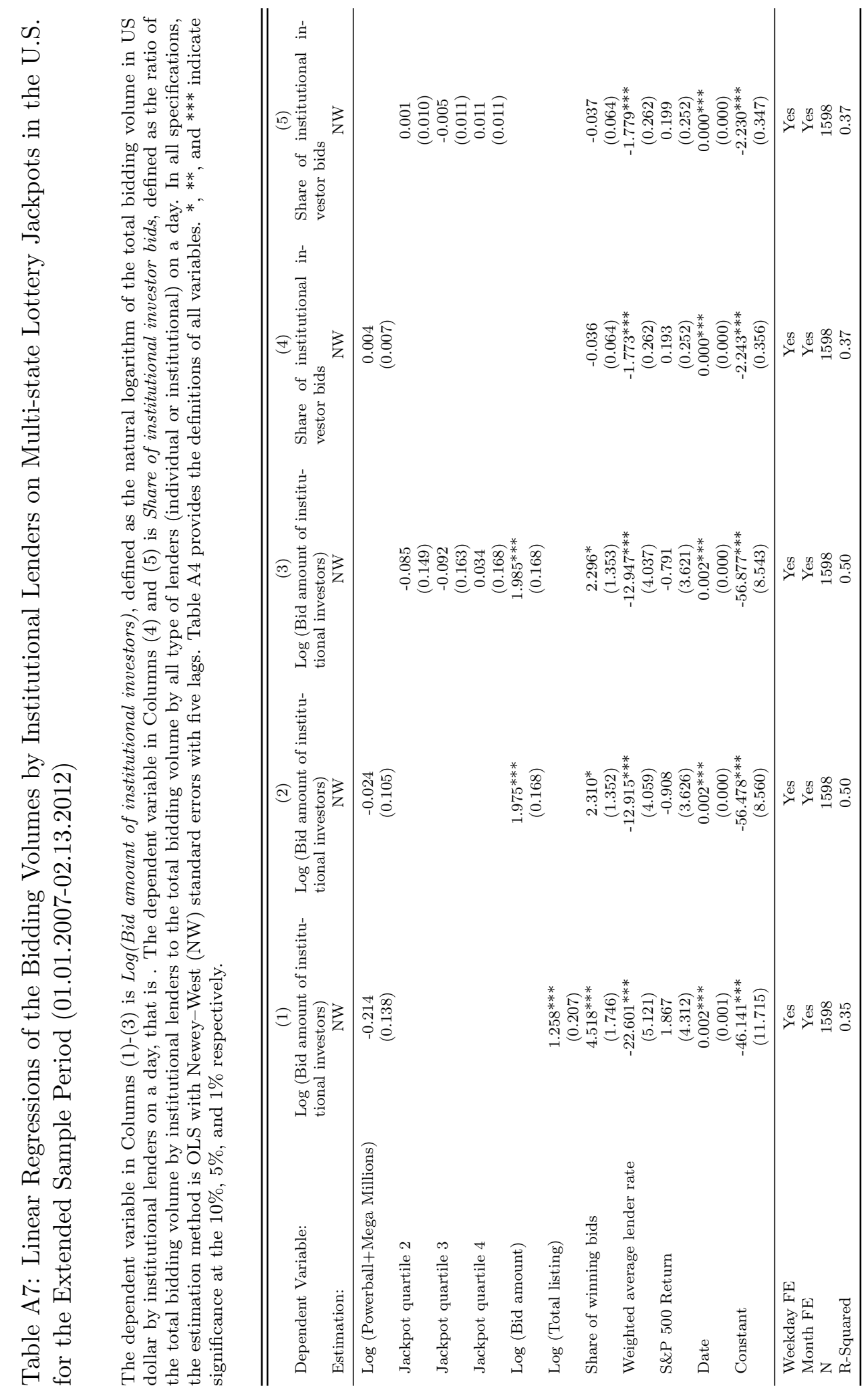

